\title{
Agro-industrial-residues as potting media: physicochemical and biological characters and their influence on plant growth
}

\author{
Pratibha Agarwal $^{1} \cdot$ Sampa Saha $^{2} \cdot$ P. Hariprasad ${ }^{1}$ \\ Received: 31 May 2021 / Revised: 9 September 2021 / Accepted: 24 September 2021 \\ (c) The Author(s), under exclusive licence to Springer-Verlag GmbH Germany, part of Springer Nature 2021
}

\begin{abstract}
Nursery cultivation is recognized globally as an intensive production system to support quality seedlings as well as to manage resources efficiently. Apart from other factors, potting media (PM) play a crucial role in determining the success of nursery cultivation. Worldwide, peat is the most commonly used substrate in PM because of its favorable physicochemical properties. However, due to ascending environmental and ecological concerns regarding the use of peat, a variety of new substrates have been used/tested by researchers/practitioners/growers as PM. Bark, coir pith, wood fiber, compost derived from various agro-residues, and vermicompost either alone or in combination are some of the commonly explored substrates and found to have the potential to replace peat to a greater extent. In lieu of availability, abundance, low cost, and no/low processing requirement, the use of agro-industrial residue (AIR) in the PM is the current trend. However, challenges associated with their adoption cannot be ignored. The present review is focused on providing collective information, scientific knowledge and detailed analysis of various AIR used in PM. The critical evidence-based review would help in developing a consistent approach for the identification, selection and characterization of a new renewable substrate. In addition, it would help in developing a rationale understanding of the practical and economic realities involved in the adoption of the same in PM.
\end{abstract}

Keywords Potting media $\cdot$ Paddy straw $\cdot$ Deoiled seed cake $\cdot$ Agro-industrial-residue $\cdot$ Peat $\cdot$ Transplant

\section{Introduction}

Transplant production, especially for vegetable and floriculture, has become popular in the last two decades to enhance resource efficiency as well as to reduce the environmental impact [1]. Early and uniform crop maturity, efficient management of land, energy, time and seed materials, production of pestfree transplants, reduction in pesticide and herbicides usage, and most importantly healthy and homogenous seedlings are some of the advantages of transplant production [2-4]. The profitable opportunities offered by this production system are the reason for the enhanced demand for seedlings, especially for the production of vegetables and flowers. Looking into

P. Hariprasad

phari@iitd.ac.in; phimprovement.iitd@gmail.com

1 Centre for Rural Development and Technology, Indian Institute of Technology Delhi, Hauz Khas, New Delhi, India

2 Department of Materials Science and Engineering, Indian Institute of Technology Delhi, Hauz Khas, New Delhi, India the advantages of the transplant system, researchers extended their applications into a wide range of plants, including sugarcane and forestry species (pine, beech, spruce, etc.) [5-7]. Ornamental plants production is another emerging horticulture sector in terms of volume, value, specialization, as well as commercialization. Quality, homogeneity, and standardized products is one prerequisite to achieve success in producing ornamentals [8]. Potting media (PM), fertilizers, permitted pesticides, seeds, labor, and the infrastructure itself is the main inputs in greenhouse nurseries and ornamental plant cultivation [1]. After labor, PM is the second prominent contributor to total greenhouse production cost [9].

Two fundamental challenges before soilless cultivation are, (i) unlike a normal soil profile, a pot provides a very shallow layer of a PM that saturates quickly during irrigation; (ii) small pot volume provides limited capacity for water storage between irrigation events [10]. Indeed, an effective PM must have a physical structure that can sustain a favorable balance between air and water content both during and between irrigation events in order to prevent root asphyxia and drought stress $[11,12]$. The inability of the 
soil to provide this balance at such small volumes is a key factor in the development of soilless PM. Indeed, these PMs have been a pivotal innovation, allowing growers to ensure rationale supply of water, air, and nutrient to the plant while excluding soil-borne pathogens [13]. Peat is the most widely used substrate in PM [13-15]. However, due to ecological and environmental concerns, the use of peat in PM is under high scrutiny. This had given a thrust to examine a wide range of alternative materials in PM. In spite of exploring a diverse range of new materials, only a few of them have been adopted widely. This review critically examines all the issues and provides an overall and comprehensive knowledge of:

(1) all the widely used substrates in PM

(2) some new renewable substrates which were not investigated in detail

(3) selection and evaluation criteria of an unconventional substrate in PM

\section{Background}

Historically, horticulturalists were using a mixture of composted organic waste and mineral soil for growing plants. Usually, the soil was not sterilized or pasteurized. Consequently, the chances of soil-borne pathogens and insect infestation were very high. Also, these mixtures were usually unbalanced in nutrition with varied physical properties reducing the consistency of PM performance. In the United Kingdom (UK), in 1930s, Lawrence and Newell standardized growing media called "John Innes" (blend of loam, sand, and peat in 7:3:2 ratio, respectively) for commercial purposes [16]. Here, the loam was sterilized to eliminate pathogens and pests. Additionally, necessary nutrients status and desirable physical properties were taken into consideration while developing the media to achieve optimum plant growth. Since loam was the main "body" of this media, its usage was limited by difficulties in transportation and handling because of its heavy weight. During 1950s in the United States (US), due to the widening of greenhouse crop production and containerized nursery, researchers and practitioners identified bark and peat as the most efficient soilless components for PM production. Later, in the 1970s, peat was explored successfully as an alternative to loam to make transportation cost effective [17].

Considering the ease of handling and beneficial properties, with time peat became the major component of PM and still dominates the sector. About 40 million cubic $\mathrm{m}^{3}$ of peat is used annually worldwide in horticultural production [18], among which Germany ( 8.5 million $\left.\mathrm{m}^{3}\right)$ and UK (2. 5 million $\mathrm{m}^{3}$ ) are the major consumers of peat in horticulture media [19].
Peatlands are highly fragile ecosystems, which are natural habitats of huge biodiversity. Peatlands contain $15-35 \%$ of regional species, among which 5-25\% are endemic [20]. Peatlands serve as a primary sink for $\mathrm{CO}_{2}$, estimated to store $75 \%$ of all atmospheric carbon. The destruction of these habitats leads to a wide range of biodiversity loss and release of active $\mathrm{C}$ into the atmosphere, thereby disturbing the global carbon cycle [21]. Adding to this, every 4 to 5 tons peat collection process from its natural habitats costs 1 ton of $\mathrm{CO}_{2}$ emission into the atmosphere making the process more hazardous [22]. In addition, the existence of this ecosystem is of crucial importance for maintaining the quality of groundwater, flood and drought mitigation, and local climate regulation [23]. A life-cycle assessment study has shown that peat-based media have the highest detrimental impact on climate change and resources [24].

Therefore, in recent years, intensive use of peat for horticulture has been discouraged due to ascending environmental concerns [25]. Since peat is identified by environmentalists as an unsustainable constituent in terms of habitat destruction pillars of sustainability [26], many peatlands are declared as special areas of conservation. The number of licenses for peat extraction has decreased in order to protect peatlands. The pressure of environmental groups has increased to reduce the use of peat in horticulture. In 2011, the UK government set specific targets for ending the use of peat in horticulture in England and Wales [27] and phasing out peat in the horticulture market by 2020 . In relation to peat extraction, the International Union for Conservation of Nature Commission on Ecosystem Management (IUCNCEM) has produced a Global Action Plan for Peatlands (GAPP). The vision statement of the GAPP recognizes the importance of peatlands and recommends wise use, conservation, and management of natural resources for the benefit of people and the natural environment [9]. In response to this, scientists and practitioners all over the world are exploring alternative substrates for replacing peat in PM [28-30].

\section{Characteristics of potting media}

Potting media play a pivotal role in the success of the nursery industry. It provides anchorage to the root system, supplies enough water and nutrients for the plant, and guarantee adequate aeration in the rhizospheric region of the seedlings and also ensures maximum transplantation success (Fig. 1) [31]. For the success of any PM, stability and consistency are essential. Further, the absence of phytotoxic chemicals, pests, and pathogens is crucial; otherwise, plant growth and health are negatively affected. Availability of raw material, cost, environmental impact, and ultimately, consumer acceptance are some of the other vital factors which cannot be ignored while choosing/developing a PM. 
Fig. 1 Characters of an ideal potting media

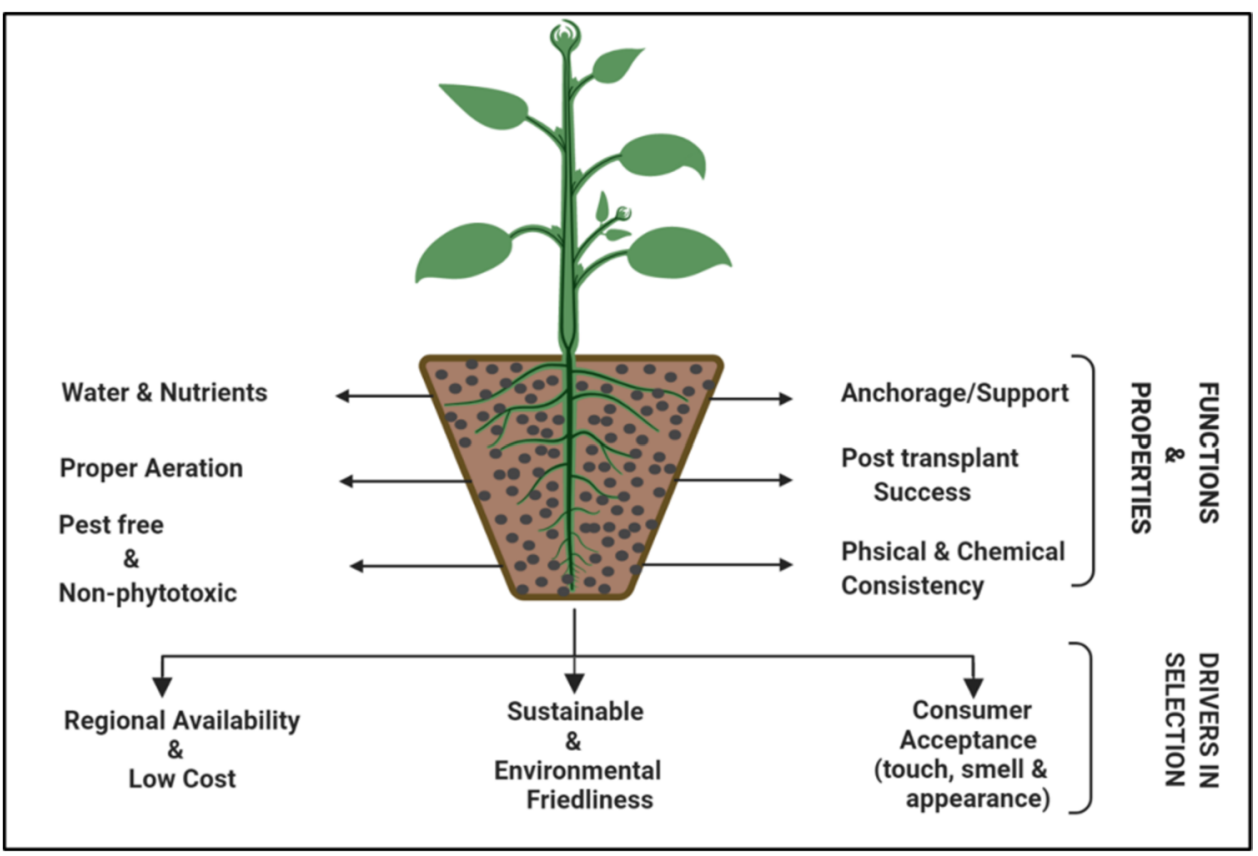

\subsection{Physio-chemical properties of potting media}

Since the volume of PM in the pot is relatively small, standardization of physical, chemical, and biological properties is of utmost importance [31]. Some of the essential physical and chemical properties are discussed below. However, the requirement may change according to plant type, environment, and management practices. Prior knowledge of these properties among growers helps in tailoring the PM according to the requirements of different plants and to obtain higher benefits from the transplants.

\subsubsection{Particle size}

It indicates the size and distribution of particles in the PM, and it is related to water retention and air porosity (Fig. 2). In general, the particle size and air porosity are directly proportional. Whereas the particle size is inversely proportional to the water-holding capacity (WHC) [32]. According to Benito et al. [33], the best substrate should contain medium to coarse texture and particle size distribution ranging between 0.25 and $2.5 \mathrm{~mm}$, which allows the retention of enough readily available water along with an adequate air content. By
Fig. 2 The interrelationship between particle size, air porosity, water-holding capacity, and their effect on plant growth and health

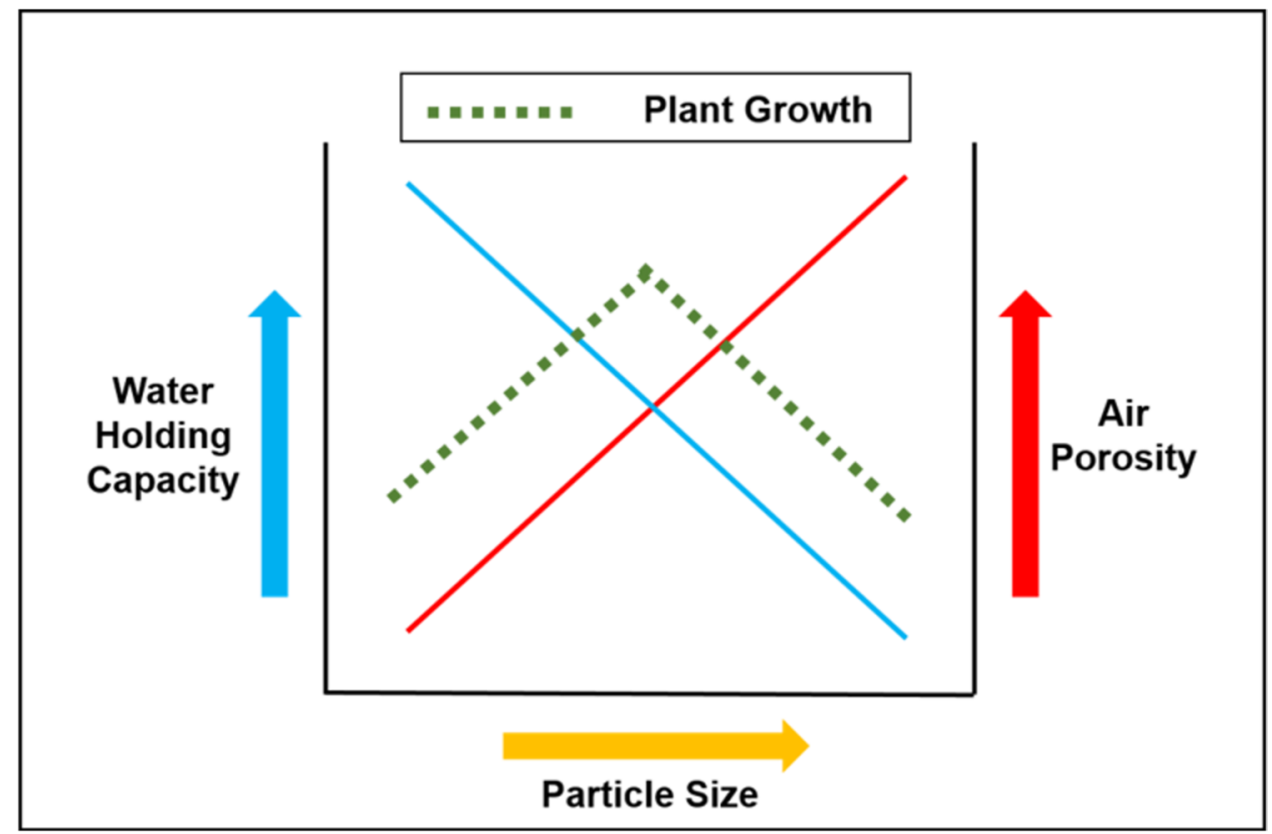


mixing eight different particle sizes $(<0.25,0.25-0.5,0.5-1$, $1-2,2-4,4-8$, and $>8 \mathrm{~mm}$ ) of pruning waste compost, a number of PM were prepared to observe the effect of particle size on physical properties. On increasing the proportion of $0.25-0.5 \mathrm{~mm}$ particles in the PM, all the physical properties (air porosity, total porosity, easily available water) tend to come in the recommended range for an ideal substrate, while increasing the proportion of particles of larger size $(0.5-8 \mathrm{~mm})$ leads to the deviation in the physical properties from the recommended values.

A PM developed by using almond shell waste had shown reduced WHC $(188 \mathrm{~mL} / \mathrm{L})$ and high air porosity $(36 \%, \mathrm{v})$ than the acceptable range $(600-1000 \mathrm{~mL} / \mathrm{L}$ and $20-30 \%$, respectively). This effect was attributed to a high proportion $(85 \%)$ of coarse $(>1 \mathrm{~mm})$ particles and a low proportion $(\approx 3 \%)$ of intermediate particles $(0.25$ to $0.5 \mathrm{~mm})$ in the PM [34]. Similarly, Samadi [35] reported that cucumber (Cucumis sativus) plants grown in fine-grade perlite had higher fruit weight (50\%), plant height (25\%), and leaf area (70\%) compared with very-coarse grade. The inferior performance of course grades of perlite could be ascribed to their low WHC rendering the plants susceptible to water stress.

\subsubsection{Bulk density}

Bulk density refers to the mass of the PM divided by the volume occupied by it. The bulk density of a PM is directly proportional to WHC and inversely proportional to air porosity. Bulk density is an important parameter while considering transportation. Raw materials or final PM or transplants with very high bulk density may not be desirable during transportation. Because of its high bulk density $\left(1.0 \mathrm{~g} / \mathrm{cm}^{3}\right)$, soil-based PM called "John Innes" developed in the UK was replaced by peat-based media to make transportation cost effective [36]. However, too low density is not good while considering the stability of PM in windy conditions, mainly when lightweight plastic pots or polythene bags are used as containers for growing nursery seedlings $[13,36]$. Many workers have suggested an optimum range for the bulk density of PM. According to Bunt [37], a bulk density of 0.4 to $0.5 \mathrm{~g} / \mathrm{cm}^{3}$ is optimum. While Abad et al. [29] and Noguera et al. [32] had given a range of 0.2 to $0.4 \mathrm{~g} / \mathrm{cm}^{3}$ to be good for PM.

\subsubsection{Total porosity}

It determines the total available free space acquired by water, air, and roots in a PM. In general, large pores are responsible for aeration, whereas small to fine pores hold water. The degree of porosity is responsible for good gas exchange capacity for the root system and providing enough available water to the plant. For an ideal PM, a total porosity of 70-90\% is recommended [29, 32], while Beardsell et al. [38] and Jaenicke et al. [39] suggested that a total porosity in the range of $50-80 \%$ can be ideal for a good PM. The presence of sufficient oxygen in the rhizosphere is crucial for plant roots. It is accepted that with less than $12 \%$ oxygen in the root system, plants would not be able to produce new roots and between 5 and $10 \%$, roots would not grow and below $3 \%$, plants would die. To maintain oxygen above $12 \%$, the porosity of $50-80 \%$ by volume is ideal for PM [40].

\subsubsection{Air porosity and water-holding capacity}

The percentage volume of the PM occupied by air after gravitational drainage is known as air porosity \%, while WHC refers to the maximum volume of water retained by the substrate after it is allowed to drain. A correct balance of water and air in the PM is crucial for plant health and growth. It is also important for regulating the frequency and volume of irrigation. If the WHC of media is low while air porosity is high, media will drain fast, imposing drought stress to the plant, demanding frequent irrigation [41, 42]. While in the case of low air porosity, aeration in media would be hindered, and roots would face the hypoxia condition.

The particle size of the PM determines the air and water pore space. Larger or coarser particles have a greater percentage of macropores, also known as air pore space, while smaller or finer particles have a greater percentage of micropores, also known as water pore space. Graceson et al. [43] reported that WHC increases with an increase in the proportion of fine particles in PM, creating more waterholding pore spaces. In addition to the substrate, WHC and air porosity depend on the container height also. Owen and Altland [44] reported that WHC decreases (14\%) while air porosity increases (9\%) linearly with an increase in container height from 3.8 to $15.2 \mathrm{~cm}$. Changes in the moisture content of the PM as a result of the combined effect of matrix and gravitation results in a vertical gradient of moisture which is higher at the bottom and lower at the top of the container. This vertical gradient in the moisture content of the PM results in an inverse relationship between air porosity and WHC. For an ideal substrate, air porosity of $20-30 \%$ and WHC in the range of 50-60\% are recommended to be good [29, 45].

\subsection{5 pH}

It refers to the concentration of hydrogen ions (protons; $\mathrm{H}+$ ) in an aqueous solution. The $\mathrm{pH}$ of the substrate is a crucial parameter affecting the mobility and availability of nutrients. Further, young seedlings are more vulnerable to $\mathrm{pH}$ extremes in comparison to mature plants [46, 47 and others]. If the $\mathrm{pH}$ is not within the desired range, nutrients can become either unavailable or toxic. At high $\mathrm{pH}(>7.5)$, the solubility of phosphate, carbonates are reduced so plants cannot utilize 
them, while at low $\mathrm{pH}(<5)$, the high solubility of aluminum and manganese can cause phytotoxicity. Further, low pH levels $(<5.5)$ reduces the availability of nitrogen, phosphorus, potassium, calcium, magnesium, sulfur, and molybdenum [48, 49 and others]. Different plants vary in their $\mathrm{pH}$ requirement for example for tomato cultivation, a $\mathrm{pH}$ of 5.8-6.7 is desirable and for cucumber, the recommended $\mathrm{pH}$ is 5.3-6.4 [31]. But for most of the plants, a pH of 5.2 to 6.5 is recommended to be optimum [29, 32]. Biological functions (water uptake by roots, transpiration, photosynthesis, $\mathrm{CO}_{2}$ assimilation, etc.) of the plants also get disturbed with temporal and spatial variations in $\mathrm{pH}$ [46-49].

The $\mathrm{pH}$ of peat is low (3.5-4.1), so it can be adjusted by adding dolomitic limestone (which contains both $\mathrm{Ca}$ and $\mathrm{Mg}$ ). However, the rate of liming depends on the decomposition state of the peat. Highly decomposed peat requires a high dosage of liming and vice versa [50,51]. In the case of coir pith (pH 4.8-6.9), instead of liming, gypsum is added to provide $\mathrm{Ca}$ and to adjust $\mathrm{pH}$ [51].

Apart from the availability of nutrients, $\mathrm{pH}$ also affects the growth of microorganisms in the PM. Generally, acidic $\mathrm{pH}$ promotes fungal growth, while an alkaline $\mathrm{pH}$ particularly $>7.5$, bacteria become more prevalent $[52,53]$. As the $\mathrm{pH}$ decreased from 8.3 to 4.5 , fugal activity increased five times exponentially [53]. Below $4.5 \mathrm{pH}$ level, all the microbial activity was inhibited because of the toxic concentration of soluble aluminum ions [53]. However, individual microbial species may have different $\mathrm{pH}$ optima.

\subsubsection{Electrical conductivity}

It is an indicator of soluble salt $\left(\mathrm{Na}^{+}, \mathrm{Mg}^{2+}, \mathrm{Ca}^{2+}, \mathrm{Cl}^{-}\right.$, $\mathrm{SO}^{2-}, \mathrm{HCO}^{3-}, \mathrm{K}^{+}, \mathrm{NO}^{3-}$, etc.) concentrations in PM [54]. A high electric conductivity (EC) has an adverse impact on germination, photosynthesis, plant vigor, and yield, thus the productivity of many crops, as well as their nutritional and economic value [58, 59 and others]. On the other hand, a very low EC value indicates a lack of available salts. During the anion exchange process, excess sodium ions can replace calcium and magnesium, leading to altered medium structure and fertility. This results in the depletion of available nutrients. A high concentration of salts in the PM negatively affects transplant health. Salinity impairs plant growth and development via water stress, cytotoxicity due to excessive uptake of ions such as sodium $\left(\mathrm{Na}^{+}\right)$and chloride $\left(\mathrm{Cl}^{-}\right)$, and nutritional imbalance. Additionally, salinity is typically accompanied by oxidative stress due to the generation of reactive oxygen species (ROS). Different plants differ in their salt sensitivity/tolerance range. Cucumber, a salt-sensitive species, EC $<2.7 \mathrm{dS} / \mathrm{m}$ should be maintained in the PM, otherwise significant yield losses are inevitable. While zucchini (moderately salt-sensitive) prefers to grow in PM with EC of 2.6 to $2.8 \mathrm{dS} / \mathrm{m}$. On the other hand, tomatoes can tolerate a salt concentration up to $2.9 \mathrm{dS} / \mathrm{m}$ without any yield losses [31]. However, an EC $<2.5 \mathrm{dS} / \mathrm{m}$ is considered optimal for the development of an ideal substrate [45], while Noguera et al. [32] reported that EC $<3.5 \mathrm{dS} / \mathrm{m}$ is suitable for PM.

\subsection{7 $\mathrm{C} / \mathrm{N}$ ratio}

The $\mathrm{C} / \mathrm{N}$ ratio of $\mathrm{PM}$ is an indicator of its stability. The $\mathrm{C} / \mathrm{N}$ ratio determines their rate of decay and the rate at which $\mathrm{N}$ is made available to plants. A C/N ratio of $20-40$ is recommended for an ideal substrate $[18,42]$. High $\mathrm{C} / \mathrm{N}$ ratio of the substrate may result in $\mathrm{N}$ immobilization and activity of microbes restricted, leading to $\mathrm{N}$ deficiency [52]. In contrast, at a low $\mathrm{C} / \mathrm{N}$ ratio, $\mathrm{PM}$ decomposes quickly and releases nitrates readily, leading to carbon and energy starvation. A low $\mathrm{C} / \mathrm{N}$ ratio can be increased by adding woody (cellulosic) materials and dead leaves, while the addition of green materials, animal wastes, and deoiled cakes can lower the high $\mathrm{C} / \mathrm{N}$ ratio [60-62 and others].

\subsubsection{Cation exchange capacity}

Cation exchange capacity (CEC) correlates to the buffering capacity of the PM [31]. The CEC of PM is a measure of the ability to adsorb and exchange cations at a given $\mathrm{pH}$ [55]. The mineral cations adsorbed on the surface of media particles serve as nutrient reservoirs available to the plant roots. For an ideal PM, a moderate CEC of 50 to $200 \mathrm{meq} / \mathrm{L}$ is desirable [56]. Higher CEC than this range may result in nutrient retention in the media, while less CEC can cause nutrient leaching [57]. A PM with high CEC provides two sets of benefits: first, it can hold more nutrient elements and give them back to the plant later; second, it can better resist any change in $\mathrm{pH}$. But $\mathrm{PM}$ with high $\mathrm{CEC}$ requires a more intense fertigation regime because many of the fertilizer elements can bind to CEC sites. Later if fertility levels decline in the PM, some of these fertilizer elements may be exchanged and then become available for plant usage [18].

Cation exchange capacity and buffering capacity of an organic component of PM depend on its age and its exposure to microbial activities. Coir pith has low buffer capacity because of low CEC (75-150 meq/L), while peat has high buffering capacity because of its high CEC (150-250 meq/L) $[56,58]$. Since most of the time, coir pith is used in its fresh form, it is low in microbial degradation and humification, which explains its low buffering capacity. Similarly, composted bark had higher CEC than fresh bark [56].

\subsection{Biological properties}

Apart from physical and chemical parameters, the biological properties of the PM are also important in determining the 
growth and health of transplants [59]. The absence of negative aspects, such as phytopathogens (fungi and bacteria), weed seeds, insects, and nematodes, are desirable for the vigor of transplants [57]. The principal weed species contaminating peat are rushes (Juncus spp.) and sheep sorrel (Rumex acetosella), growing on the margins of the bogs. Under such situations, PM may act as primary inoculum which spreads the pathogen or weeds to agricultural fields along with transplants. So, these are either controlled on-site either by manual inspection and removal or off-site; during composting, high temperature kills the seeds, propagative vegetative organs, insects, and pathogenic microbes [51]. Similarly, Ghosh et al. [60] reported the removal of pathogenic microbes, Salmonella spp. and Escherichia coli, after composting of coir pith. Heat pasteurization (moist heat from steam, aerated steam, or boiling water; dry heat from the flame, electric pasteurizers, or microwave ovens and solar heat) is another popular method to disinfect the PM [15].

In positive aspects, the presence of beneficial microorganisms can interact with the plant by acting as biofertilizers, biostimulants, and/or biopesticides, permitting the reduction of inputs in a sustainable production system [61]. Pseudomonas, Bacillus, Stenotrophomonas, Serratia, Arthrobacter, and Trichoderma are some of the well-known plant growth-promoting microorganisms [62-67]. Amendment of beneficial microorganisms ( $T$. virens, $T$. harzianum, and $T$. asperullum) into coir pith-based PM was found to improve not only growth (plant height, numbers of flowers/plant, and leaf area) of okra (Abelmoschus esculentus) and Amaranthus (Amaranthus viridis) but \% diseases incidence was reduced significantly in comparison to control (without Trichoderma) [68]. Similarly, after co-inoculation of two plant growthpromoting rhizobacteria, Pseudomonas fluorescens and Azospirillum brasilense introduced in sterilized vermiculitebased PM in marigold, a remarkable improvement in shoot fresh weight, root dry weight, leaf number, and essential oil yield were measured in treated plants in comparison to control under greenhouse condition after 90 days of inoculation [69]. Similarly, these beneficial microbes are also used to manage several soil-borne plant pathogens. Jangir et al. [70] found $56 \%$ reduction in the disease in tomatoes after mixing T. harzianum- and B. subtilis-based talc formulation at the rate of $10 \mathrm{~g} / 4 \mathrm{~kg}$ in the PM in the net house study.

Plant growth-promoting rhizobacteria (PGPR)-mediated growth promotion occurs due to two mechanisms; direct (facilitation of $\mathrm{N}, \mathrm{P}$, and essential mineral acquisition and modulation of plant hormones) and indirect (biocontrol mechanisms such as competition, niche exclusion, induced systematic resistance and antifungal metabolites $(\mathrm{HCN}$, phenazine, tensin, HCN, phenazines, pyrrolnitrin, 2,4-diacetylphloroglucinol, pyoluteorin, viscosinamide and tensin)) [71].
$\mathrm{N}$ fixation Even after being present in a plentiful amount (78\%) in the environment, $\mathrm{N}$ remains unavailable to plants. PGPR converts it to utilizable forms (ammonia) by using a complex enzyme nitrogenase [72]. Nitrogenase is a metalloenzyme with two components; dinitrogenase reductase (iron protein) and dinitrogenase. Dinitrogenase reductase provides electrons with high reducing power, while dinitrogenase uses these electrons to reduce $\mathrm{N}_{2}$ to $\mathrm{NH}_{3}$. It is an energy-consuming process as 16 ATPs are used to converts one molecule of nitrogen to ammonia [73] (Eq. 1).

$\mathrm{N}_{2}+8 \mathrm{H}+8 \mathrm{e}^{-}+16 \mathrm{MgATP} \rightarrow 2 \mathrm{NH}_{3}+\mathrm{H}_{2}+16 \mathrm{MgADP}+16 \mathrm{Pi}$

Phosphate solubilization Plants can uptake the phosphorus in two soluble forms; monobasic $\left(\mathrm{H}_{2} \mathrm{PO}_{4}{ }^{-}\right)$and dibasic $\left(\mathrm{HPO}_{4}{ }^{2-}\right)$. Various microorganisms residing in the rhizosphere that help plants in providing soluble forms of phosphorus are known as phosphorus-solubilizing microorganisms (PSMs). Azotobacter, Bacillus, Beijerinckia, Burkholderia, Enterobacter, Erwinia, Flavobacterium, Microbacterium, Pseudomonas, Rhizobium, and Serratia are some significant phosphate solubilizers [71]. The main mechanism of solubilization of inorganic phosphorus is secretion of various organic acids in the surrounding environment. The organic acid with carboxyl and hydroxyl ions chelate cations or reduce the $\mathrm{pH}$, resulting in the release of phosphate. While in the case of organic phosphorus, phytases and acid phosphatases bring out mineralization.

Siderophore Iron is a vital nutrient for all forms of life. In an aerobic environment, iron occurs mainly as $\mathrm{Fe}^{3+}$ and is likely to form insoluble hydroxides and oxyhydroxides, inaccessible to both plants and microorganisms [74]. Bacteria releases siderophores which are low molecular weight iron chelators. About 500 kinds of siderophores are known with diverse structures broadly classified as hydroxy carboxylate-, catecholate-, or hydroxamate-type siderophores [75]. Siderophores make a complex with iron (siderophoreiron complex). Plants can uptake the iron from this complex through three mechanisms: direct uptake of the complex, ligand exchange, and chelator degradation.

Phytohormones Most important direct mechanism of PGPR is auxin/IAA production. About $80 \%$ of rhizospheric bacteria synthesize auxins [76]. The endogenous auxin level of plants is altered due to microbial auxins. Microbial auxins interfere in various plant physiological functions (cell division, extension, and differentiation; seed germination; the rate of xylem and root development; vegetative growth; lateral and adventitious root formation; responses to light and gravity; photosynthesis, pigment formation, biosynthesis of various metabolites, and resistance to various stresses) mediated by endogenous auxins. Bacterial IAA increases root surface area and length and thereby provides the plant 
greater access to soil nutrients. Also, rhizobacterial IAA loosens plant cell walls and as a result, facilitates an increasing amount of root exudation that provides additional nutrients to support the growth of rhizosphere bacteria [77].

Considering the importance of these beneficial microorganisms, formulations (dry products such as wettable powders, dust, and granules, and liquid products including cell suspensions in water, oils, and emulsions) of several different microorganisms (fungi and bacteria) are available in the market, for example, T. harzianum, T. asperellum, T. viride, and Bacillus spp.-based preparations are marketed for suppression and/or control of Pythium damping off, Rhizoctonia solani and vascular wilt diseases [78, 79]. In addition, the rhizosphere-established beneficial microbes continue their service even after transplanting into fields.

Plant-associated microbiome is also known as the "second genome of the plant" as it plays a crucial role in overall plant growth and development [80]. The role of PM composition on microbial communities' structure and their potential functionalities is an emerging area of research. Grunert et al. [81] examined two PMs, organic (white peat:coir fibers, $80: 20 \%$, v/v) and inorganic (rock wool), for their community composition over time and compared the distribution of individual taxa across PMs and their potential functionality. Based on the relative abundances of the bacterial families and on the measures of alpha diversity and evenness, the presence of distinctive and stable microbial communities associated with each PM was observed. Some bacterial families such as Chitinophagaceae, Xanthomonadaceae, Flavobacteriaceae, Hypomicrobiaceae, Microbacteriaceae, Comamonadaceae, Enterobacteriaceae, Methylophilaceae, Rhizobiaceae, Pseudomonadaceae, and Sphingobacteriaceae were present in abundances in both PM. Further, Chitinophagaceae, Methylophilaceae, and Hypomicrobiaceae were abundant in organic PM. Organic PM has shown higher microbial diversity in comparison to inorganic PM. However, the organic PM had shown a similar abundance of microorganisms at different time points, while inorganic PM had shown variations in abundance with time. In a similar study, Koohakan et al. [82] reported that organic (coconut fiber) PM was mainly colonized by fungi, while in the case of inorganic (rockwool) PM, bacteria are more dominant. The reason may be that presence of organic nutrients in organic PM shifted the microbial equilibrium through reduced competition. Further population density analysis with time revealed that bacterial population became stabi-

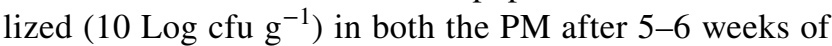
cultivation. But in the case of fungi, it was found to increase till the end of the experimental period. All these studies validate that there are fundamental differences between the microbiome of different PMs; consequently, the structurally diverse microbial community inhabiting the PM provides functional diversity, ultimately affecting the quality of PM and plant growth.

A significant interaction exists between microbial community and PM with respect to plant growth. Same bacterial community performed differently in different PM with respect to plant growth [83]. Total phenolic content (TPC) of lettuce was not significantly different in plants grown either in bark compost or green waste compost. However, inoculating both the PM with the same microbial community raised the TPC of lettuce grown in composted bark PM while the TPC levels observed in the green waste compost growing media were unchanged [83]. In a similar study, Vandecasteele et al. [84] reported that biocontrol fungi showed better colonisation in defibrated miscanthus, reed straw, and flax shives in comparison to peat. Since peat does not provide necessary nutrients for microbial growth and proliferation. In peat also, white peat stimulates microbial activity in comparison to black peat because highly decomposed peat, i.e., black peat is a less favorable source of energy for microbes [83]. Inorganic materials such as rock wool and perlite may provide a physical surface for adherence to microbes, but they would not support microbial growth and proliferation because of the absence of an organic $\mathrm{C}$ source.

Different organic materials might influence the composition of mineralizing microorganisms. Addition of miscanthus straw to PM altered the rhizospheric fungal community. As miscanthus straw is a better $\mathrm{C}$ source, so providing a profitable opportunity for colonisation of decomposer fungi such as Chaetomium and Humicola sp., [85]. Nerlich and Dannehl [86] found that among wood chips, rock wool, peat, and hemp fibers, hemp fibers have shown the highest degradability (30\% within 8 weeks of crop cycle). High microbial biomass developed on hemp consumed the $\mathrm{O}_{2}$ from substrate solution and led to $\mathrm{O}_{2}$ deficiency in the rhizosphere zone of the plant. Further, nitrogen from the substrate solution was used in the build-up of this high microbial biomass, reducing the availability of nitrogen for plants resulting in retarded plant growth in hemp substrate in comparison to other substrates (peat, rock wool, and wood chips).

Apart from the chemical composition of PM substrate, the physical characteristics of PM also affect microbial activity. Water-filled pores of the PM influences the microbiome of PM. At low water content, the supply of solutes to microbes is reduced, while at high water content, pores filled with water reduces the $\mathrm{O}_{2}$ availability and metabolic activity of aerobic microorganisms. Generally, the optimal moisture content is approximately $60 \%(\mathrm{v} / \mathrm{v})$ for microbial activity; however, individual microorganisms respond differently to water stress [87]. Grunert et al. [81] found that Agrobacterium $\mathrm{sp}$. was detected in organic (peat:coir; 80:20\%, v/v) and rock wool substrate, but plants grown in organic PM were lack of visually detectable hairy roots. These results indicate that differences in pore size and water distribution between 
organic and rock wool may have impacted the mobility of Agrobacterium sp., resulting in decreased hairy roots.

The stability of PM is another biological property, which is crucial in PM success, which is governed by several above discussed physicochemical and biological parameters. Decomposition of PM either during the period of storage or usage may bring undesirable changes in physical and chemical properties, which affect the plant growth performance [96, 97 and others]. Alteration in particle size, a decrease in air content, increase in water content, shrinkage, compaction, change in the gaseous phase (due to $\mathrm{CO}_{2}$ generation), alteration in $\mathrm{pH}, \mathrm{CEC}$, and salinity are some of the changes associated with the decomposition of the potting substrates with time [57].

Noguera et al. [32] had suggested a shrinkage $<30 \%$ volume be acceptable for the growing medium. The shrinkage of the medium tends to increase bulk density, thus increasing the water retention and correspondingly decreases both total and air-filled porosities. Since shrinkage reduces aeration in the growth medium and may even elevate the risk of waterlogging and hypoxia for plants grown in those media that possess high water retention and are persistently kept near container capacity. However, shrinkage of PM can be decreased by the addition of coarse inert material such as perlite, rock wool, etc. [9, 88].

The major part of organic PM substrate is made up of lignocellulose; however, depending upon the origin, the composition may differ. Lignocellulose is a complex structure with three main constituents; cellulose, hemicellulose, and lignin [89]. Cellulose is a linear polymer of glucose with $\beta-1,4$-glycosidic bond, while hemicellulose is a polysaccharide made of monomeric sugars and sugar acids such as xylose, arabinose, mannose, glucose, galactose, glucuronic acid, galacturonic acid, and methyl glucuronic acid linked together by $\beta-1,4-$ and $\beta-1,3$-glycosidic bonds [ 90 , 91]. Lignin is a complex amorphous heteropolymer with a three-dimensional structure composed of phenylpropane derivates linked to each other by the irregular coupling of $\mathrm{C}-\mathrm{C}$ and $\mathrm{C}-\mathrm{O}$ bonds $[89,92]$.

There are high chances that during usage or storage, various microorganisms may degrade the PM and affect the stability of the same. Cellulases hydrolyse the $\beta-1,4-$ glycosidic linkage bonds that connect glucose units in the cellulose fiber. They are categorized into three major classes: endoglucanases, exoglucanases, and $\beta$-glucosidase [90]. Trichoderma reesei, Trichoderma harzianum, Aspergillus niger, Pesralotiopsis sp., Phanerochaete chrysosporium, Fomitopsis palustris, and Neocallimastix frontalis are some main cellulose-degrading fungi [89]. Whereas two types of enzymes: endo-1,4- $\beta$-xylanase and exo-1,4$\beta$-xylosidase, are involved in hemicellulose degradation. Trichoderma longibrachiatum, Aspergillus nidulans,
Sclerotium rolfsii, Aspergillus niger, and Phanerochaete chrysosporium are common hemicellulose degraders [91].

Lignin degradation is mediated through the action of laccase, manganese-dependent peroxidases (MnP), lignin peroxidases (LiP), and versatile peroxidases (VP). Trametes pubescens, Coriolus hirsutus, Trametes hirsute, Trametes versicolor, Pycnoporus cinnabarinus, Neurospora crassa, Pleurotus ostreatus, Botrytis cinerea, Phanerochaete chrysosporium, Mucor racemosus, and Aspergillus sclerotiorum are well-known lignin degraders [92].

At present, due to the globalization of horticulture and floriculture-related activities, generally, PM is transported to a longer distance and remains stored up to years before use. During this time, microbial-mediated changes in physical and physicochemical properties may occur, which affect the plant growth negatively at the time of its use. Changes in PM properties during storage were highlighted first time by Bunt for Johnes Innes media in the 1950s [93]. Mineralization of organic fertilizer during storage of this media may lead to changes in $\mathrm{pH}$, ammonical, and nitrate-nitrogen concentrations with subsequent adverse effects on plant growth. Peat, having unique pectin-like substances (sphagnan), which is resistant to microbial attack so depletion of nutrients rarely occurs in peat during storage. Due to the presence of sphgnan (antimicrobial compound) in the cell wall, peat moss was historically used in wound dressing [94]. However, there are some reports of self-heating of peat during storage, leading to the production of phytotoxic compounds rendering the PM unmarketable [95, 96]. However, other commonly used substrates such as bark, wood fiber-based media are rich in cellulose and hemicellulose, resulting in rapid microbial colonization and quick depletion of nutrients, especially nitrogen, during storage. This nutrient draw-down has a detrimental effect on plant growth [59, 93]. Some of these problems can be overcome by blending the PM with more stable components or by fertilizing the media with additional nutrients at the time of application. However, prediction and correction of biological problems of PM are major challenges before the horticulture industry [97].

\section{Components of potting media}

There is not one unanimous PM used around the world. Generally, growers try to use locally manufactured or available cheap products and often, two or more substrates are mixed to obtain a desirable media. However, PM components may be broadly divided into two categories: organic and inorganic constituents. 


\subsection{Organic constituents}

Presently organic materials dominate the PM market [98]. Among them, peat moss, coir pith, and composts are commonly used organic substrates.

\subsubsection{Peat}

Peat is derived from peatlands, an ecosystem containing accumulated partially decomposed organic matter under anaerobic and waterlogged conditions [10]. Peatlands may be classified into three types on the basis of botanical composition; wood peat (remains of trees and shrubs), sedge peat (sedges, grasses, and herbs), and moss peat (bryophyte mosses, e.g., sphagnum). Among all the peats, the most widespread and common peatlands are moss peat, particularly those derived from the incomplete decomposition of the bryophyte Sphagnum [50]. Peatlands are found from arctic to tropical regions occupying 3\% of the earth's land area $[20,99]$. More than $90 \%$ of all known peatland area is found only in 6 countries, i.e., Russia, Canada, USA, Finland, Sweden, and Indonesia [23, 100].

Peat is a very well-known substrate for its high nutrition exchange capacity, WHC, high salt buffering capacity, and good aeration quality. These qualities make it the most widely used organic material in PM $[14,19,51]$. Low salinity $(0.39-0.49 \mathrm{mS} / \mathrm{cm})$ [101] and low $\mathrm{pH}(3.5-4.1)$ [50] of the peat can be adjusted by liming, while the low nutrient status of peat, can be easily adjusted by the addition of cropspecific fertilization [50]. However, operational difficulties were observed, resulting in uneven mixing of plant nutrients and lime, leading to heterogeneously mixed PM [101]. A low number of pathogens, pests and weeds and finally easy handling, processing, grading, and blending are some of the positive aspects which encourage the gardeners for its horticultural use [16].

\subsubsection{Bark}

In the southeastern USA, New Zealand, Australia, and some European countries, a large quantity of soft and hardwood bark are obtained as a byproduct of the lumber, paper, and pulp industry. Here, barks of pine (Pinus spp.), spruce (Picea spp.), and Acacia (Acacia melonxylon) are some of the commonly used components of PM [102]. The bark is a very lightweight material with low bulk density, high air porosity, and low WHC [50]. It enhances drainage and improves aeration in the substrate. Similar to other PM, the quality of transplant will depend on the botanical origin, particle size distribution, and composting of bark [9]. The presence of phenolic compounds, terpenes, acetic acid, etc. in native bark has a protective effect against microbial diseases; contrarily, they are also toxic to plant growth. However, secondary process treatments (hydrothermal treatment, aging, composting, etc.) can be employed to eliminate toxic compounds [102, 103]. In the case of Eucalyptus globulus, the phytotoxicity of bark-based PM to cress (Lepidium sativum) seeds can be reduced by hydrothermal treatment [104]. Whereas douglas fir bark (Pseudotsuga menziesii) requires aging to remove phytotoxicity against geranium (Pelargonium hortorum) [105].

In European countries, Australia and the USA, bark is composted for inclusion as a component of PM. Apart from the elimination of phytotoxic components, composting help in killing phyto pathogens, pests, and weed seeds. The risk of $\mathrm{N}$ immobilisation is higher in the bark, especially with low lignin content (Picea) in comparison to high lignin-containing bark (Pinus). Composting helps in reducing the risk of nitrogen immobilisation due to microbial colonisation. Apart from plant growth promotion activity, composted bark is well known for its disease suppressive effect [56, 106]. Usually, hardwood bark [107] and eucalyptus bark [108] are composted and used in PM intending to suppressing various plant pathogens.

\subsubsection{Wood fiber}

Wood fiber is a stable, consistent, and sterile secondary product formed due to mechanical fibrillation or steamassisted thermal extrusion of de-barked softwoods and virgin wood chips, such as spruce (Picea spp.), pine (Pinus spp.), fir (Abies spp.), Poplar (Populus spp.), etc. Among hardwoods, ash (Fraxinus), willow (Salix), and beech (Fagus) are commonly used [19]. Maritime pine and spruce are the main raw material used in PM in France and Germany [50]. Wood fiber is characterized by high air (47-48\%) and high total porosity (>90\%) and low WHC and is generally used for improving the physical properties of other PM components (reducing bulk density and WHC, enhancing air porosity) [31,50].

The research work of Prasad and Maher [109] and Domeño et al. [110] evidenced that during the crop cycle, wood fiber undergoes compression, thereby a reduction in air porosity of PM. Hence, wood fiber cannot be used as a standalone substrate for crop production [98, 111]. Nitrogen content in wood fiber is relatively very low, so supplementary nitrogen is added either during the manufacturing process or by the grower. There is no issue of phytotoxicity with the wood fiber, as observed in the case of bark fiber. However, due to the growing demand for wood products and the emergence of wood material as the renewable fuel material in the background of the energy crisis, the future of wood fiber usage in PM is uncertain. 


\subsubsection{Coir pith}

It is derived from the mesocarp tissue or husk of coconut (Cocos nucifera L.), commonly known as "Lakshmi Phal." India is the largest producer of coconut in the world, followed by Indonesia and the Philippines [112]. The husk is composed of short and long fibers and coir dust. The long fibers extracted from husk are used in various products such as brushes, mattings, and insulating materials. The remaining material consisting of short fibers and coir dust is known as coir pith and is used in horticulture [51, 113, 114]. The husk is soaked in water to facilitate the extraction of the fibers. Often, brackish water is used, so it increases the sodium and potassium levels in the coir pith. The high concentration of $\mathrm{Na}^{+}$and $\mathrm{K}^{+}$may be phytotoxic during its application as PM [50]. Several rounds of washing in fresh water and a "buffering" treatment, in which calcium nitrate is used to remove the high concentrations of sodium and potassium, are required before it is used as a PM [51]. But this secondary treatment increases the cost of coir pith significantly.

In many studies, coir pith is reported as a potential substrate for replacing peat in PM [115, 116]. Coir pith is light in weight, has good aeration, good WHC reported to retain up to 9 times of water of its weight $[9,117]$. Additionally, in comparison to peatmoss, rewetting capacity is good [118]. Since coir pith has more lignin (30-31\%) and less cellulose $(26.8 \%)$ in comparison to peat, so it is comparatively more stable than peat [119]. However, CEC of coir pith is lower $(39-60 \mathrm{cmol} / \mathrm{kg}$ ) than peat moss $(90-140 \mathrm{cmol} / \mathrm{kg}$ ) [120]. Coir pith has an optimum $\mathrm{pH}$ (5.5-6.8) for most of the plants' growth while peat is highly acidic, so, usage of coir pith reduces the cost of cultivation by eliminating the cost of liming as required in the case of peat $[9,121,122]$. So, in recent years, coir pith emerged as a major component of PM [51, 117]. Exports of coir pith from India primarily for horticulture use have increased tremendously [51, 123].

\subsubsection{Compost}

Compost is a stabilized organic material produced as a result of a long, mesophilic as well as thermophilic aerobic and/ or anaerobic process that inhibits viable weed seeds and pathogens [124]. Traditionally, compost was developed from plant waste material only. However, nowadays, agriculture waste, yard waste, food industry waste, municipal organic waste, and even human and animal manures are subjected to composting [125, 126]. Compost is rich in nutrients and organic matter improves the physical and chemical properties of the PM and increases the availability of macro- and micronutrients and growth regulators for transplant growth [125]. Some waste materials used as a feedstock for composting and subsequently used in PM are summarized in Online resource 1. Apart from plant growth-promoting activity, compost may be used to adjust the $\mathrm{pH}$ of PM. Pardo et al. [127] found that addition of olive mill waste compost and lime separately to acidic soil $(\mathrm{pH}=6.97)$ resulted in an almost similar $\mathrm{pH}$ increase (7.41 and 7.42 for compost and lime, respectively).

There are variations in physicochemical properties of various composts, which make them either less or more suitable for usage in PM. Manure (cattle dung, poultry litter, swine waste, etc.) contain various human and animal pathogens such as Escherichia coli, Listeria monocytogenes, and Salmonella spp. Although these pathogens are destroyed at high temperatures during composting but still quality assurance is required while using manure compost in PM [128]. High salinity is another major hindrance in the use of manure, spent mushroom, and vegetable, fruit, and garden waste (VFG) composts [129, 130]. Municipal solid waste (MSW) derived compost also contains high salt, high $\mathrm{pH}$, and heavy metal content [131]. The presence of microplastic and glass fragments in the MSW compost is another issue that needs attention before using it in PM. A recent study indicates that plants grown in compost containing micro plastic result in the accumulation of microplastic in plant tissues [132]. Green compost (derived mainly from gardens, parks, consisting of chiefly woody materials), low in salt content, are comparatively more suitable for inclusion in PM [130].

In general, the high $\mathrm{pH}$ and high salinity of the compost render it incompatible with the plants [133, 134], so compost is not used solely as PM. Therefore, the compost is always blended with other materials most preferably with peat and coir pith to enhance the suitability for crop production [19, 135]. In some cases, pretreatment of the feed stock prior to composting may help in reducing the salinity. Wet sieving of MSW prior to composting enhance the organic matter and reduce the salt content. The enhanced amount of compost in PM provide high disease suppressiveness against Pythium ultimum (from 31 to 94\%) [136]. Similarly, washing treatment of animal-derived waste before composting was found to be effective in reducing the salinity of manure compost [129].

Another strategy to bring down the alkalinity of compost is through acidification of the compost. Elemental S (S0) is added to compost, the autotrophic bacteria (Thiobacillus spp.), heterotrophic bacteria, and fungi oxidize the elemental $\mathrm{S}$ to $\mathrm{H}_{2} \mathrm{SO}_{4}$, thereby reducing the $\mathrm{pH}$ of compost. The amount of elemental $\mathrm{S}$ is required to acidify the compost depends on the buffering capacity of the compost. Compost with high buffering capacity (animal manure compost) requires a higher amount of $\mathrm{S}$ in comparison to low buffering capacity having compost (e.g., wood compost). The impact of $\mathrm{pH}$ buffering capacity on compost acidification is well illustrated by the comparison between dairy solids and mint hay compost. Prior to acidification, both of these composts had a $\mathrm{pH}$ value of 8.1. However, after acidification, 
$\mathrm{pH}$ dropped to 5.1 in mint hay compost and only to 7.0 in dairy solids compost because the high buffering capacity of dairy solids compost was about twice that of the mint hay compost [137].

\subsubsection{Vermicompost}

Vermicompost is the earthworm processed fine organic waste with high porosity, aeration, drainage, and water-holding capacity $[148,149]$. It is well known organic fertilizer for promoting plant growth as it contains nutrients in readily available forms such as nitrates, exchangeable phosphorus, potassium, calcium, and magnesium [150, 151]. In addition to this, it also contains substances such as phytohormones (auxins and cytokinins), involved in regulating plant growth and health and humic acid, which play an important role in enhancing nutrient uptake by the plants [149, 151-155]. Vermicompost is reported to be a suitable soil amendment/ conditioner because it improves porosity, drainage, aeration, and WHC [148, 149]. Since vermicompost is rich in organic matter, the CEC of the soil was found to be enhanced [148], which enables more $\mathrm{Na}^{+}-\mathrm{Ca}^{2+}$ exchange; as a result, much more $\mathrm{Na}^{+}$is leached into drainage water and soil salinity is reduced [156]. Several earlier research evidenced the beneficial properties of vermicompost on plant growth when used as PM amendments and the positive effect was attributed to either correlated with improved physical, chemical, and biological properties of PM after vermicompost amendments [157-159].

\subsubsection{Biochar}

Biochar is a solid charred material obtained from pyrolysis at a temperature ranging from 400 to $700{ }^{\circ} \mathrm{C}$ of biomass either in the absence or limited supply of oxygen. In recent years, it gathered attention as a component of PM due to some of its desirable properties; $100 \%$ biochar-based $\mathrm{PM}$ is not practically feasible due to undesirable physicochemical properties. Even at a 70\% amendment rate, biochar negatively affected plant growth due to osmotic stress and inhibition of mycorrhizal activity [160]. So, there is a need to find out the appropriate proportion of the biochar to be amended in PM. The $\mathrm{pH}$ of the biochar is alkaline, so it can neutralize the acidity of peat, thereby reducing the requirement of lime [161]. The high CEC and high nutrient-holding capacity of biochar reduce nutrient leaching and enhance the buffering capacity of amended PM. Headlee et al. [162] found that biochar-amended PM (peat:biochar, 75:25\%, v/v) had shown high CEC in comparison to only peat-based $(100 \%, \mathrm{v}) \mathrm{PM}$. The addition of biochar to peat-based medium at the rate of 5\% and $10 \%$ provides sufficient $\mathrm{P}$ and $\mathrm{K}$ without any nutrient deficiency symptoms in container-grown horticultural crops (pansy, sunflower, tomato, zinnia, and geranium) [163]. Similar results of enhanced nutrient availability and improved fertility of PM upon addition of biochar has been observed by several other authors.

Due to its low bulk density, it reduces the risk of PM compaction. Because of the high water retention capacity, the frequency of irrigation can be reduced. Mendez et al. [164] found that the addition of biochar from deinking sludge to peat $(50 / 50 \%, \mathrm{v} / \mathrm{v})$ resulted in increased air space, water-holding capacity, and total porosity in comparison to only peat-based (100\%) PM. Similarly, Zhang et al. [165] reported that incorporation of biochar in composted green waste (CGW) reduced the bulk density, improved the waterholding capacity, and porosity in comparison to CGW alone. Due to high surface area and porous structure, biochar provides more sites of microbial colonization and proliferation [166]. Inoculation with arbuscular mycorrhizae in PM amended with optimum concentration of biochar significantly enhanced the Pelargonium growth [160]. Therefore, recent studies have investigated the use of biochar as carrier material for microbial inoculants, especially as seed coatings $[167,168]$.

However, the physical and chemical properties of biochar depend on raw material and pyrolysis condition (temperature, residence time, etc.) [169]. Song and Guo [170] had suggested that for agricultural use, the temperature should be between 300 and $500{ }^{\circ} \mathrm{C}$, while for carbon sequestration and environmental purpose, a temperature higher than $500{ }^{\circ} \mathrm{C}$ was found to be optimum. However, biochar obtained at $300{ }^{\circ} \mathrm{C}$ from pruning waste of different gardens had shown phytotoxicity against lettuce because of the presence of a significant amount of polyphenols in biochar. Whereas biochar obtained at $500{ }^{\circ} \mathrm{C}$ recorded low polyphenols content, thereby relieving phytotoxicity [171]. Generally, biochar affects plant growth either positively or it is neutral towards plant growth when it is amended to PM in more than $25 \%$ (v/v) $[161,172]$.

\subsection{Inorganic components}

Inorganic components are meant for providing a structural system of pores for improving drainage and aeration in the $\mathrm{PM}$. These components are mostly chemically inert and high in bulk density. They provide a sterile base along with stability to the nursery containers $[15,81]$. Inorganic constituents are costly, non-renewable, and difficult to dispose of in comparison to organic counterparts. All these properties indicate that these substrates are not sustainable options for PM [98]. Inorganic constituents can be classified into two categories: processed (rock wool, vermiculite, perlite, zeolite, expanded clay, etc.) and unmodified natural materials (sand, tuff, pumice, etc.) [173]. 


\section{Untransformed agro-industrial residues: moving forwards}

To replace the usage of peat moss in the potting substrate, researchers across the world explored various abundantly available local agro-industrial residues (AIRs) for testing their potential as a component for PM (Table 1). The idea of the usage of AIR is based on the assumption that reuse has less environmental impact than disposal. Because of low secondary processing requirements, these materials require fewer inputs and manipulation, and since most of them are abundant and locally available, their transportation is also cost effective and their negative impact on the environment is comparatively least.

To optimize the physical, chemical, and biological properties of the AIRs, several pretreatments can be employed. Steam explosion, retrusion, extrusion, hammer milling, grinding, and disc refining are some of the common methods of defibration of AIRs [18, 84]. Defibration affects not only the basic features (amount of cellulose, hemicellulose, lignin, $\mathrm{pH}, \mathrm{Ec}$, water-extractable $\mathrm{C}$ ), but it also affects microbial activity, thus it is linked to the risk of $\mathrm{N}$ immobilization. The effect of defibration on plant fiber is not straightforward. It depends on the characteristics of plant fiber and the method of defibration. Extrusion, retrusion, and disc refining significantly reduced the risk for $\mathrm{N}$ immobilization for miscanthus straw. Acidification of miscanthus straw, flax shives, and reed straw with acetic acid and citric acid reduced the $\mathrm{pH}$ of the fibers, resulting in a reduction in the risk of $\mathrm{N}$ immobilization. Acidification of fibers set the $\mathrm{pH}$ outside the optimal range of microbial action, reducing the microbial activity; consequently, the risk of $\mathrm{N}$ immobilization was also reduced [84].

Contrarily, when an organic material with high $\mathrm{C} / \mathrm{N}$ ratios (plant fibers/straw) are microbially colonized, leading to competition between plant and microbes for available $\mathrm{N}$ and other nutrients. $\mathrm{N}$ immobilization in pure miscanthus straw was higher $(70 \pm 12 \%)$ than pure peat $(0 \pm 16 \%)$ [85]. Similarly, Vandcasttele et al. [84] reported that reed straw, miscanthus straw, and flax shives have a comparatively high risk of $\mathrm{N}$ immobilization compared to peat. There are several strategies to overcome this $\mathrm{N}$ immobilization, such as the addition of $\mathrm{N}$ fertilizers, treatment with $\mathrm{N}$-containing acid $\left(\mathrm{HNO}_{3}\right)$ [174], shifting the $\mathrm{pH}$ from the optimal range of microbes, etc. [84]. Also, nitration of plant fibers (saw dust, flax shives, rye straw) with nitric acid enhanced the availability of $\mathrm{N}$ [174].

Conventional organic PM, i.e., peat is not a good medium to harbor beneficial microorganisms because of its high amount of stabilized carbon, low available energy reserves does not provide food and nutrients for the growth and development of biocontrol agents [175]. While plant fibers with a high holocellulose/lignin ratio are more easily colonized by biocontrol agents compared to peat [84]. The plant fibers can be used as a carrier for colonization and proliferation of biocontrol microorganisms such as Trichoderma, Chaetomium, Gliocladium, and Metarhizium anisopliae. Debode et al. [85] incorporated 20\% Trichoderma-precolonized extruded miscanthus straw in peat and observed a reduction in postharvest disease incidence of strawberry due to induction of defence-related genes in the leaves.

\subsection{Deoiled cakes: an untapped substrate with huge potential}

Oilseed cakes are the residue obtained after extraction of oil from the plant source by cold press or solvent extraction method. The byproduct obtained by pressing is termed oil cake and that by solvent extraction, oil meal [176]. Oil cakes are of two types: edible and non-edible. Those cakes resulting from edible oil-bearing seeds, which are being used to meet a part of the nutritional requirements of either animal-feed or of human consumption, are called edible oil cakes (e.g., mustard (Brassica juncea), groundnut (Arachis hypogaea), sesame (Sesamum indicum), etc.). Those who cannot be used as feedstuff due to the presence of toxic compounds and other impurities are differentiated as non-edible cakes (e.g., neem (Azadirachta indica), jatropha (Jatropha curcas), mahua (Madhuca indica), Karanja (Pongamia pinnata), etc.) $[176,177]$.

Many of the deoiled cakes are well known for their nematicidal potential [178-180]. Neem cake amendments (30 g/kg soil) to PM recorded reduced root-knot nematode (Meloidogyne incognita) (egg masses/root system, number of galls/plant, nematode population) infection in tomato [181]. Similar observations were recorded by Radwan et al. [179] when seasame cake was used at $50 \mathrm{~g} / \mathrm{kg}$ soil. Apart from being nematicidal in nature, various deoiled cakes have been reported to have anti-fungal properties also [182].

It is crucial to highlight that deoiled seed cakes are rich in NPK and other essential micronutrients such as $\mathrm{Ca}, \mathrm{Mg}, \mathrm{Cu}$, $\mathrm{Mn}, \mathrm{Zn}$, and Fe [181, 182]. Some of the researchers tested deoiled cakes (cotton, mustard, neem, castor) for their plant growth-promoting potential and reported a positive effect on various plant growth parameters and enhanced nutrient status [181-183]. Lesquerella press cake had the level of nutrients that it can serve as an organic fertilizer for container-grown plants. $10 \%$ (w/w) amendment of cake in PM was equivalent to the chemically fertilized control in terms of plant heights, total yield per plant and number of fruit per plant in tomato [184]. Similarly, maximum growth of castor plants was recorded in sandy soil-based media amended with castor meal $(4.5 \%, \mathrm{v} / \mathrm{v})$, and after this highest growth point $(4.5 \%, \mathrm{v} / \mathrm{v})$, a pronounced reduction in growth was observed [185]. It seems that rapidly mineralizing nitrogen 
Table 1 Various agro-industrial residue used in potting media

\begin{tabular}{ll}
\hline Materials used & Observation \\
\hline Peanut hulls (PH) & $\begin{array}{c}\text { Azalea's (Rhododendron indicum L.) growth (shoot and root dry weight) was recorded } \\
\text { better in PH (100\%, v) based media in comparison to PH + Peat (50:50\%, v/v) media, }\end{array}$ \\
& $\begin{array}{l}\text { Peanut hull }(100 \%) \text { based media has recorded increased particle size, total porosity, and } \\
\text { air space and decreased easily available water in comparison to PH and peat (50:50\%) }\end{array}$ \\
& based media, so necessary adjustment in irrigation regime was done \\
& Two horticultural crops (tomato and melon) performed equivalently in almond shell \\
& waste-based media and control (rockwool) in terms of various fruit parameters (fruit \\
& number, firmness, dry weight content, soluble sugars, and yield). However, the air \\
& porosity of the almond shell waste media (40\%) was higher than the ideal substrate \\
& (30\%) while WHC (194 mL/L) was lower. Still, deficient physical properties had not \\
& affected plant growth negatively provided necessary adjustments in irrigation manage- \\
& ment were adopted \\
& Cyclamen (Cyclamen persicum L.) performed either equally or better in peat and RH \\
& based growth medium (90:10\%, v/v) than the control (peat:perlite (90:10\%, v/v)) \\
& with respect to growth parameters (plant height, dry corm weight, dry root weight, \\
& dry flower weight). However, on increasing the volume of rice hull in the peat media \\
& from 10 to $50 \%$, a progressive reduction in all the growth parameters was recorded and \\
& resulted in smaller plants thus decreasing the market value of the product
\end{tabular}

Poinsettia (Euphorbia pulcherrima L.) and geranium (Pelargonium $\times$ hortorum) have shown similar growth in $10 \% \mathrm{RH}$ and $10 \%$ perlite-based media (rest being peat in both the media). On increasing the RH volume in the media to $30 \%$ and $50 \%$, both the plants have shown poor growth performance because of increased $\mathrm{pH}$, total pore space, air porosity, reduced electrical conductivity and WHC

Fresh rice hulls substituted perlite successfully and used with peat in a 3:1 ratio for Pinus (P. halepenis) seedling cultivation

Switchgrass

A PM having switchgrass (80\%) with peat $(20 \%)$ was developed for growing annual vinca (Catharanthus roseus). Pine bark (100\%) was used as control. Switchgrass has high air porosity and reduced WHC, and alkali in nature. However, the addition of peat moss enhanced WHC, reduced the air porosity and reduce the $\mathrm{pH}$ of the media making it more ideal for annual vinca growth

Miscanthus straw (MS) Peat (15\%) and municipal solid waste compost (MSWC) (5\%) were used as the base material. Remaining $80 \%$ was consisting of pine bark and MS in five different ratios 0:80, 20:60, 40:40, 60:20, and 80:0. From 20 to $60 \%$ MS addition, $\mathrm{pH}$ was moderate and Red hibiscus (Hibiscus moscheutos) plants were of higher quality and recorded comparable foliar color, and a similar size to those grown in the industry-standard PM (pine bark:peat:MSWC, 80:15:5\%, v)

Wheat straw (WS) Peat and perlite $(85: 15 \%, \mathrm{v} / \mathrm{v})$ were used as control. This base material was amended with $40 \%$ WS. The addition of WS had increased the air porosity $(27 \%)$, reduced the container capacity $(58 \%)$ and bulk density $\left(0.08 \mathrm{~g} / \mathrm{cm}^{3}\right)$ of the PM in comparison to control (peat:perlite; $85: 15 \%$, v/v) $\left(13 \%, 70 \%\right.$, and $0.10 \mathrm{~g} / \mathrm{cm}^{3}$, respectively). Despite having differences, all the studied parameters were within the recommended range. Although there were differences in nutrient content among daylily (Hemerocallis fulva 'Stella D'Oro'). But plants displayed none of the classic deficiency symptoms of interveinal or marginal chlorosis

Corn stover (CS) Tomato (Solanum lycopersicum L.) and marigold (Tagetes patula L.) plants grown in a CS-amended media (peat:CS:perlite, 3:1:4, v/v/v) were inferior to those grown in control (peat:perlite, $4: 4, \mathrm{v} / \mathrm{v}$ ) in terms of greenness, tallness, flower and fruit number. The addition of CS to PM negatively affected the physical and chemical characteristics (reduced available water, $\mathrm{N}$ and $\mathrm{P}$ content and increased $\mathrm{pH}$ ) of the media

Fig leaf powder

Red soil, Coir powder, leaf (Ficus elastic) powder and sand, either alone or in different combinations, were tested for their effect on different growth parameters of Dalbergia (Dalbergia odorifera T. Chen). Among all the eighteen combinations, coir powder and red soil $(2 / 2, \mathrm{v} / \mathrm{v})$ and red soil and sand $(2 / 2, \mathrm{v} / \mathrm{v})$ based media exerted the best effects on plant growth and biomass accumulation. Leaf powder and red soil $(2 / 2, \mathrm{v} / \mathrm{v})$ enhanced root system development remarkably. However, the reason behind these observations was not discussed by the authors

Reference(s)

Bilderback et al. [138]

Urrestarazu et al. [34]

Bonaguro et al. [139]

Zanin et al. [140]

Tsakaldimi and Ganatsas [6]

Atland [141]

Altland and Locke [142]

Locke and Altland [143]

Ruis et al. [144]

Yue et al. [145] 
Table 1 (continued)

\begin{tabular}{|c|c|c|}
\hline Materials used & Observation & Reference(s) \\
\hline Reed canary (RC) & $\begin{array}{l}\text { Vegetative growth of the strawberry (Fragaria } \times \text { ananassa cv. Elsanta) was vigorous } \\
\text { in peat }(100 \%) \text { media but total yield, berry size and sugar to the acid ratio in berries } \\
\text { were not significantly different between RC amended media (peat:RC } 50: 50 \%, \mathrm{v} / \mathrm{v} \text { ) and } \\
\text { control (peat, } 100 \%) \text {. Since the WHC of RC amended media was lower than control, a } \\
\text { change in the irrigation regime is required }\end{array}$ & Kuisma et al. [18] \\
\hline Paper waste (PW) & $\begin{array}{l}\text { The addition of PW to peat increased the substrate } \mathrm{pH} \text {, and decreased air-filled poros- } \\
\text { ity. Considering all the growth parameters (plant height and diameter, leaf and flower } \\
\text { fresh weight, leaf and flower diameter, total biomass), a partial replacement of peat } \\
\text { with PW (up to } 30 \% \text { ) was suggested for marigold (Calendula Officinalis L) and petunia } \\
\text { (Petunia } \times \text { hybrita } \mathrm{L} \text { ) but not for mathiola (Matthiola incana } \mathrm{L} \text {.). Possible causes of } \\
\text { decreased growth of mathiola on PW amendment can be attributed to the different } \\
\text { responses of the species to decreased WHC and air-filled porosity on PW amendment }\end{array}$ & Chrysargyris et al. [22] \\
\hline Poultry feather feathers & $\begin{array}{l}\text { On addition of poultry feather fibers }(30 \%, \mathrm{v} / \mathrm{v}) \text { to peat moss and perlite-based medium } \\
(80: 20 \%, \mathrm{v} / \mathrm{v}) \text { by replacing peat, reduction in the WHC }(69.4 \mathrm{vs} .52 .3 \%) \text { and increase } \\
\text { in air-filled porosity }(10.9 \mathrm{vs} .30 .6 \%) \text { was recorded. Since on addition of feather fibers, } \\
\text { the percentage of large pores filled with air increased and the percentage of small pores } \\
\text { responsible for WHC decreased }\end{array}$ & Evans and Vancey [146] \\
\hline River waste (RW) & $\begin{array}{l}\text { In comparison to control (peatmoss:vermiculite:perlite, } 70: 20: 10 \% \text {, v/v), river waste } \\
(\mathrm{RW}) \text { based medium (RW:vermiculite:perlite, } 80: 10: 10 \%, \mathrm{v} / \mathrm{v}) \text { had recorded higher dry } \\
\text { weight for petunia }(\text { Petunia } \times \text { hybrida) and impatiens (Impatiens wallerana), and in the } \\
\text { case of violet (Viola wittrokiona) dry weight was not significantly different from that of } \\
\text { control }\end{array}$ & Benedetto et al. [147] \\
\hline Hemp fibers & $\begin{array}{l}\text { Highly degradable hemp fibers ( } 30 \% \text { within } 8 \text { weeks of cultivation) lead to enhanced } \\
\text { microbial colonisation, } \mathrm{O}_{2} \text { deficiency and nitrogen draw down resulted in poor plant } \\
\text { growth }\end{array}$ & Nerlich and Dannehl [86] \\
\hline Flax shives & $\begin{array}{l}\text { This risk of } \mathrm{N} \text { immobilisation was higher in flax shives in comparison to peat, so the } \\
\text { availability of } \mathrm{N} \text { to plants was reduced. Flax shives are colonized by plant pathogens } \\
\text { such as Verticillium dahliae. During defibration at high temperatures, microsclerotia of } \\
\text { the pathogen are killed. Defibrated falx shives are easily colonized by fungal biocontrol } \\
\text { agents in comparison to peat }\end{array}$ & Vandecasteele et al. [84] \\
\hline
\end{tabular}

from the deoiled cakes is the reason for both the intensive plant growth in low doses and the reduction of plant growth in high doses.

While Gupta et al. [186] amended the soil with castordeoiled cake and found that growth of the wheat plant was negatively affected if the castor cake was applied on the sowing day, however, the application of cake 20 days before wheat sowing resulted in improved growth in comparison to control. Authors attributed this effect to an unknown toxin present in the raw deoiled cake, which was degraded during the decomposition.

The raw deoiled cake had specific metabolites, high salts or ionic species (e.g., ammonia), which may be phytotoxic to plants [179, 187]. Some of the oil cakes, such as mustard cake, result in the generation of excess ammonium ion formation in the PM [188]. Ammonium ion represents either a preferential $\mathrm{N}$ source, or it may trigger toxicity symptoms in plants depending on its concentration. In response to the high concentration of ammonium ion, most of the plants develop a typical root toxicity symptom, "short root" [189]. A similar observation was reported by Pratibha et al. [190] for tomato and cucumber after the amendment of PM with raw mustard cake (Fig. 3). In the case of jatropha cake, phorbol esters are mainly responsible for phytotoxicity. Phorbol ester toxicity is known to cause various physiological and morphological changes in the plant. Phorbol esters are responsible for the activation of many isoforms of protein kinase- $\mathrm{C}(\mathrm{PKC})$, which is a cell protein that regulates many cellular processes in the cell cycle and leads to a reduction in mitotic index [191, 192], resulting in decreased root growth [193]. However, during the decomposition of deoiled cake, due to microbial mediated detoxification, the phytotoxic property of the raw cake is relieved [187]. Ahluwalia [187] found that even at the lowest concentration (1\%) of raw jatropha cake affected seed germination of Vigna radiata negatively. However, the detoxified jatropha cake failed to exert any negative effect even at 5\% amendment. A similar observation was recorded by Wang et al. [194] observed in the case of tobacco plants grown in jatropha/detoxified jatropha cake as PM amendment. Though several deoiled cakes are phytotoxic, their low concentrations amendments depending on the sensitivity of plants may be beneficial as it does not require any secondary treatment.

Further, depending on the agroclimatic conditions, the availability of different deoiled cakes varies globally. So a proper and exhaustive assessment of the worldwide 
Fig. 3 Effect of mustard cake amendments on the root growth of cucumber (Cucumis sativus L.) seedlings

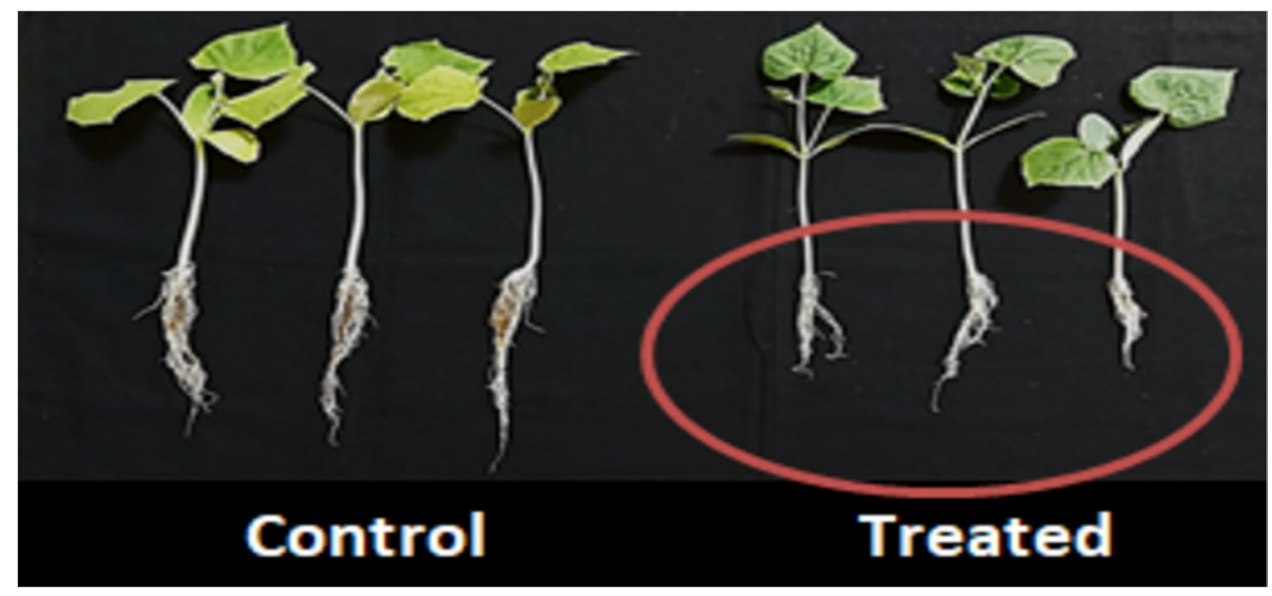

distribution of different deoiled cakes is of prime importance. Further, wherever deoiled cakes are produced abundantly, e.g., developing countries, efforts are needed by government organizations, research communities to mobilize them in forms that can be used by the farmers more easily.

\subsection{Paddy straw: problem or opportunity}

Global paddy straw (PS) production is estimated to be around 731 million tonnes; out of this, 667 million tonnes are generated in Asia only [195]. In India, the paddy crop produces 160 million tonnes of straw with 106.5 million tonnes of grain per annum [196]. Management of the PS is a major problem in comparison to other residues such as wheat straw because of time constraints between rice harvest and wheat sowing. Since PS is rich in silica, it is not preferred as animal feed. Further, in the era of mechanized agriculture, dependency on animals is reduced, so the number of animals used in agriculture is also reduced. Among all residue management options (burning, bailing, in situ incorporation in the soil, removal), burning is considered the most feasible method by farmers. Consequently, the burning of one ton of PS produces about $1460 \mathrm{~kg} \mathrm{CO}_{2}, 3 \mathrm{~kg}$ particulate matter, $60 \mathrm{~kg} \mathrm{CO}, 199 \mathrm{~kg}$ ash, and $2 \mathrm{~kg} \mathrm{SO}$ [197]. Polycyclic aromatic hydrocarbons (PAHs), dioxins, furans are some carcinogenic compounds that are also released during the burning of PS [198]. Paddy straw contains about 0.78, $0.24,1.15 \%$, and $14 \%$ of the nitrogen $(\mathrm{N})$, phosphorus $(\mathrm{P})$, potassium (K), and silica ( $\mathrm{Si})$, respectively [199, 200]. By considering the nutrient dynamics, PS burning depletes the soil vital nutrients (particularly $\mathrm{N}$ ) and reduces soil organic matter [201].

The elemental form of silica, i.e., silicon ( $\mathrm{Si}$ ), is not considered an essential element for plant growth, but this element is beneficial for plant growth, particularly under biotic (plant pathogens, insects, mites, etc.) and abiotic (drought, salinity, high or low temperature, UV irradiation, metal toxicity, etc.) stress conditions [202-204].
Composting, mushroom cultivation, biochar, building material (bricks, fiberboard, etc.), hi-end material (silica, biofiber), biogas, and bioethanol production are some offfield options for straw management [205]. Many of the workers had used PS compost in PM [206, 207] for the cultivation of various horticultural crops. However, raw PS is not widely explored because of some common problems associated with the AIR such as phytotoxicity, nitrogen immobilization, high salt content, or structural incompatibility. Recently, some preliminary investigations have been done to explore the possibility of using raw PS as a component of PM for some crops.

In the field, PS is commonly used as a mulching agent. Also, tomatoes cultivated by utilizing PS bales recorded better yield (number of fruits/plant and weight/fruit) compared to those grown in clay soil (control). Further, the observation was attributed to improved aeration to the roots of tomato plants [208]. Similarly, PS (size $<2 \mathrm{~mm}$ ) combined with vermicompost $15 \%(\mathrm{v} / \mathrm{v})$ increased vegetative growth and total yield of lettuce (Lactuca sativa) and eggplant (Solanum melongena L.) significantly [209]. Along with improved plant growth and yield of pepper, PS bales also protected the plants from fungal root rot and wilt and root-knot nematodes significantly over control [210].

Since PS is chiefly a lignocellulosic material that is not rich in N. In order to compensate for the nitrogen shortage of PS as the PM, Sadek et al. [211] used two free-living nitrogen-fixing bacteria Azotobacter chroococcum and Paenibacillus polymyxa for the cultivation of eggplant. Authors reported a significant increase in fresh and dry weight, number of fruits and fruit weight in eggplant after co-inoculation of both the bacteria in comparison to control. Recently, Pratibha et al. [190] compensated the low N content of the PS-based PM by adding N-rich organic matter (different deoiled cakes) for the cultivation of tomato and cucumber under greenhouse conditions. Here, the positive effect of PS addition $(10 \%, v)$ in PM on plant growth was attributed to improved physical properties (air porosity, WHC, total 
porosity) of the PM. Since PS addition improved the aeration of PM, the possibility of using it as a replacement of perlite (an inorganic component generally used to enhance aeration in PM) should be explored in the future.

\section{Selection and evaluation criteria of an unconventional substrate in potting media}

\subsection{Regional availability and abundant supply}

In most cases, individual nursery or greenhouse operators do not have the resources to produce and process their own AIR; therefore, a regional biomass assessment needs to be performed. This entails interviewing local horticultural producers and identifying acceptable soilless substrate components within the region. It is equally important to ensure a secure supply of the AIR. For many of the novel AIR investigated to date, scanty information has been published on the potential volumes that might be available relative to market demand and the long-term security of supply. The results of this basic investigation into these factors would be extremely useful both to PM manufacturers and the wider research community. While agro-industries have historically generated large volumes of organic wastes/residue. Though these AIRs were explored for various applications, as PM they are least explored. Hence, their broader applications may deplete the availability of these materials for horticultural use. It is therefore crucial that going forwards, economics related to material supply and volume should be carefully analyzed both by the researchers and users.

\subsection{Environmental impact and assessment}

Since the idea of using waste in PM is based on the assumption that reuse has less environmental impact than disposal. A detailed life-cycle assessment (LCA) analysis is required to support this claim. The entire life cycle of a substrate should be assessed in terms of climate change, ecosystem quality, and human health. For example, coir pith is considered a sustainable option for replacing peat in Europe. In terms of its impact on climate change, this is probably the case; but in terms of ecosystem quality and human health, it performs less favorably than peat [24]. The adverse impact on human health was attributed to the emission of NOx and particulate matter during the transport of decompressed coir pith to the mixing plant. Recently, some detailed LCA analysis of the already existing substrates (sewage sludge-based compost, rice hulls, etc.) had been performed [139, 212, 213], but more emphasis or thrust should be given to such kind of analysis before adopting any substrate at the commercial level.

\subsection{Phytotoxicity}

Screening of any new/unconventional substrate starts with testing the material for its effect on plant growth. If the substrate is phytotoxic/reduces the plant vigor unacceptably, it cannot be selected as a substrate in PM [30, 102]. The phytotoxicity of AIR may be because of high sodium and potassium content [51], phenols, terpenes, tannins [51, 102], fatty acids [178], and generation of ammonia [179]. Washing, aging, composting, mixing, and fertilization are some of the methods used to reduce or eliminate phytotoxicity. The time and cost involved in each treatment should be taken into consideration before opting for any of the substrates.

\subsection{Consistent performance}

These natural substrates are heterogeneous in physical, chemical, and biological properties depending upon their origin, processing, and storage conditions. In the case of transformed waste such as compost, vermicompost, the situation becomes more complicated because a slight change in secondary processing may create large differences in the properties of the material despite having one origin/source [214]. It is crucial to pursue a quantitative assessment of the physical, chemical, and biological properties which influence the material's performance and a detailed description of the secondary processing, treatments, or additives is also required. This will allow groups of materials to be better defined, benefits to be more clearly aligned with costs, and more consideration would be afforded to the practical realities of using the material. During the nursery cultivation process also, it is desirable that the substrate should perform consistently. Any change in physical and chemical properties (shrinkage, compaction, $\mathrm{pH}, \mathrm{EC}$, etc.) during this stage may hamper the plant performance.

\section{Reuse/recycling of spent PM}

Reuse or recycling of spent PM is another step towards a sustainable/circular horticulture system. Spent PM can be reused as PM with or without modifications. High degradability/low stability, presence of harmful microorganisms (animal and plant pathogens), weed seeds, high residual nutrient, and salt content are some of the major challenges in the reuse of spent PM $[215,216]$. On reuse, a highly degradable substrate in PM may result in $\mathrm{O}_{2}$ deficiency [86], altered physicochemical properties and nutrient depletion, and thus compromise plant growth, which must be studied in detail. Pythium, Phytophthora spp., Salmonella spp., and E. coli are some of the common plants and animal pathogens that remained associated with used PM. Therefore, the cultivation of crops in spent PM may increase the risk of 
root-borne diseases. Sanitation treatment kills both harmful and beneficial microorganisms, affecting the whole microbiome of the PM. Spent PM is tested for several crops either with treatment (steam sterilization) [217] or without any treatment [218]. The results are inconsistent; sometimes, growth was positively affected, while in some cases, clearly no effect on plant growth was reported. Further, the result of sanitation treatment is substrate-specific. Peat could not be reused after steam treatment due to the breakdown of its structure. However, steam-treated coir pith performed equally to fresh PM with respect to strawberry vigour and growth [217].

However, their use as a bulking agent for composting [219], as soil improver [220], and as feedstock for energy are widely practised. Biochar production from the spent PM is another way of recycling. Amery et al. [169] tested biochars derived from spent PM and lignocellulosic biomass. Biochars produced from spent PM were characterized by higher EC, extractable and total nutrient concentrations compared with biochars derived from lignocellulosic biomass, but spent PM-derived biochars have not affected plant growth negatively.

\section{Conclusion and future scope}

Historically, performance and economics were the two main drivers in PM development, but nowadays, environmental impact is one of the key factors. In the case of horticulture $\mathrm{PM}$, reliance on just one non-renewable material (peat) is not a sustainable model for the long term. It is necessary to explore a broader range of renewable materials in lieu of the dynamic nature of the demand/supply chain for organic material resources against a background of the rapid growth of the transplant industry. While selecting any new substrate, availability, location, and the environmental impact of the substrates should be thoroughly analyzed and assessed.

Researchers and manufacturers need to continue exploring the use of renewable primary materials in conjunction with valuable waste streams. In this context, waste of various agro-industries such apple pomace, orange peels, paper pulp industry, vegetable industry, etc., may be potential options, which were never explored before as PM. The use of various AIR would also help in the channelization and management of waste so these industries turn towards green. However, the development of standard protocols to bring uniformity in the production process and quality improvement in $\mathrm{PM}$ is to be taken care. The PM of the future will most likely rely upon blends of several ingredients, taking advantage of their beneficial properties while minimizing their limitations. Finally, consumer acceptance of texture and color can be achieved by branding and awareness programs.
Supplementary Information The online version contains supplementary material available at https://doi.org/10.1007/s13399-021-01998-6.

Acknowledgements The authors are profoundly grateful to the Director, Indian Institute of Technology Delhi, for providing all the necessary facilities to conduct this research work. Pratibha acknowledges the Council for Scientific and Industrial Research (CSIR), Government of India for providing fellowship (09/086(1259)/2016-EMR I).

Author contribution Pratibha: idea, literature search, and data analysis. Sampa Saha: critical revision. Hariprasad P.: idea, data analysis, draft preparartion, and critical revision.

Data availability Not applicable.

Code availability Not applicable.

\section{Declarations}

Conflict of interest The authors declare no conflict of interest.

\section{References}

1. Restrepo AP, Medina E, Pérez-Espinosa A et al (2013) Substitution of peat in horticultural seedlings: Suitability of digestate-derived compost from cattle manure and maize silage codigestion. Commun Soil Sci Plant Anal 44:668-677. https:// doi.org/10.1080/00103624.2013.748004

2. Unal M (2013) Effect of organic media on growth of vegetable seedlings. Pakistan J Agric Sci 50:517-522. https://www.resea rchgate.net/publication/279220515 effect_of_organic media on_growth_of_vegetable_seedlings. Accessed 29 Aug 2021

3. Chrysargyris A, Saridakis C, Tzortzakis N (2013) Use of municipal solid waste compost as growing medium component for melon seedlings production. J Plant Biol Soil Heal 2:1-5. https://doi.org/10.13188/2331-8996.1000005

4. Marinou E, Chrysargyris A, Tzortzakis N (2013) Use of sawdust, coco soil and pumice in hydroponically grown strawberry. Plant, Soil Environ 59:452-459. https://doi.org/10.17221/297/ 2013-pse

5. Singh SN, Yadav RL, Lal M et al (2011) Assessing feasibility of growing sugarcane by a polythene bag culture system for rapid multiplication of seed cane in sub-tropical climatic conditions of India. Plant Prod Sci 14:229-232. https://doi.org/10.1626/pps.14. 229

6. Tsakaldimi M, Ganatsas P (2016) A synthesis of results on wastes as potting media substitutes for the production of native plant species. Reforesta. https://doi.org/10.21750/refor.1.08.8

7. Banach J, Małek S, Kormanek M, Durło G (2020) Growth of Fagus sylvatica L. and Picea abies L. karst. seedlings grown in hiko containers in the first year after planting. Sustainability 12:. https://doi.org/10.3390/su12177155

8. Barrera Necha LL, Bautista-Baños S (2016) Chapter 8 - prospects for the use of chitosan and other alternatives in ornamental conservation. In: Bautista-Baños S, Romanazzi G, JiménezAparicio A (eds) Chitosan in the preservation of agricultural commodities. Academic Press, San Diego, pp 221-249. https:// doi.org/10.1016/B978-0-12-802735-6.00008-2

9. Pascual JA, Ceglie F, Tuzel Y, et al (2018) Organic substrate for transplant production in organic nurseries. A review. Agron Sustain Dev 38:. https://doi.org/10.1007/s13593-018-0508-4 
10. Bunt BR (1988) Media and mixes for container-grown plants, 1st ed. Springer Netherlands. https://doi.org/10.1007/ 978-94-011-7904-1

11. Fonteno WC (1993) Problems \& considerations in determining physical properties of horticultural substrates. Acta Hortic. https://doi.org/10.17660/actahortic.1993.342.22

12. Caron J, Nkongolo VKN (1999) Aeration in growing media: recent developments. Acta Hortic. https://doi.org/10.17660/ actahortic.1999.481.64

13. Raviv M, Wallach R, Silber A, et al (2002) Substrates and their analysis. Hydroponic Prod Veg Ornamentals 25-101. https:// www.researchgate.net/publication/313419715_Substrates_ and_their_analysis. Accessed 29 Aug 2021

14. Kitir N, Yildirim E, Şahin Ü, et al (2018) Peat use in horticulture. In: Peat. https://doi.org/10.5772/intechopen.79171

15. Wilkinson KM, Landis TD, Haase DL, et al (2014) Tropical nursery manual-a guide to starting and operating a nursery for native and traditional plants. Agric Handb 732 378. https:// www.fs.fed.us/rm/pubs_series/wo/wo_ah732.pdf. Accessed 29 Aug 2021

16. Kern J, Tammeorg P, Shanskiy M et al (2017) Synergistic use of peat and charred material in growing media-an option to reduce the pressure on peatlands? J Environ Eng Landsc Manag 25:160-174. https://doi.org/10.3846/16486897.2017.1284665

17. Alexander PD, Bragg NC, Meade R, et al (2008) Peat in horticulture and conservation: the UK response to a changing world. Mires Peat 3:1-10. http://pixelrauschen.de/wbmp/media/map03/ map_03_08.pdf. Accessed 29 Aug 2021

18. Kuisma E, Palonen P, Yli-Halla M (2014) Reed canary grass straw as a substrate in soilless cultivation of strawberry. Sci Hortic (Amsterdam) 178:217-223. https://doi.org/10.1016/j.scienta. 2014.09.002

19. Schmilewski G (2009) Growing medium constituents used in the EU. Acta Hortic 819:33-46. https://doi.org/10.17660/ActaH ortic.2009.819.3

20. IUCN (2017) Peatlands and climate change. In: Int. Union Conserv. Nat. - Issues Br. https://www.iucn.org/resources/issuesbriefs/peatlands-and-climate-change. Accessed 9 Sep 2021

21. Parish, F. Sirin, A. Charman, D. Joosten, H. Minayeva, T. Silvius, M. and Stringer L (2008) Assessment on peatlands, biodiversity and climate change: main report. Global Environment Centre, Kuala Lumpur and Wetlands International, Wageningen. In: Assess. Peatlands, Biodivers. Clim. Chang. main report. http:// www.imcg.net/modules/download_gallery/dlc.php?file $=35 \&$ id $=$ 1311192068. Accessed 29 Aug 2021

22. Chrysargyris A, Stavrinides M, Moustakas K, Tzortzakis N (2019) Utilization of paper waste as growing media for potted ornamental plants. Clean Technol Environ Policy 21:1937-1948. https://doi.org/10.1007/s10098-018-1647-7

23. Joosten H, Clarke D (2002) Wise use of mires and peatlandsbackground and principles including a framework for decisionmaking. In: Int. Mire Conserv. Gr. Int. Peat Soc. http://www. imcg.net/media/download_gallery/books/wump_wise_use_of_ mires_and_peatlands_book.pdf. Accessed 29 Aug 2021

24. Quantis (2012) Comparative life cycle assessment of horticultural growing media based on peat and other growing media constituents. European Peat and Growing Media Association156, https:// www.warum-torf.info/download/comparative-life-cycle-asses sment-of-horticultural-growing-media-based-on-peat-and-othergrowing-media-constituents. Accessed 29 Aug 2021

25. Van Os EA (1999) Closed soilless growing systems: a sustainable solution for Dutch greenhouse horticulture. Water Sci Technol 39:105-112. https://doi.org/10.1016/S0273-1223(99)00091-8

26. Carlile B, Coules A (2013) Towards sustainability in growing media. Acta Hortic. https://doi.org/10.17660/actahortic.2013. 1013.42
27. Bragg N, Brough W (2014) The development of responsibly sourced growing media components and mixes. Acta Hortic 1055:141-144. https://doi.org/10.17660/ActaHortic.2014.1055. 30

28. Robertson RA (1993) Peat, horticulture and environment. Biodivers Conserv. https://doi.org/10.1007/BF00056747

29. Abad M, Noguera P, Burés S (2001) National inventory of organic wastes for use as growing media for ornamental potted plant production: case study in Spain. Bioresour Technol 77:197-200. https://doi.org/10.1016/S0960-8524(00)00152-8

30. Bilderback TE, Riley ED, Jackson BE, et al (2013) Strategies for developing sustainable substrates in nursery crop production. Acta Hortic 1013:43-56. https://doi.org/10.17660/ActaHortic. 2013.1013.2

31. Savvas D, Gianquinto GP, Tüzel Y, Gruda N (2013) Good agricultural practices for greenhouse vegetable crops - principles for Mediterranean climate areas. In: FAO Plant Prod. Prot. Pap. 217. http://www.fao.org/3/i3284e/i3284e.pdf. Accessed 29 Aug 2021

32. Noguera P, Abad M, Puchades R et al (2003) Influence of particle size on physical and chemical properties of coconut coir dust as container medium. Commun Soil Sci Plant Anal 34:593-605. https://doi.org/10.1081/CSS-120017842

33. Benito M, Masaguer A, Moliner A, De Antonio R (2006) Chemical and physical properties of pruning waste compost and their seasonal variability. Bioresour Technol 97:2071-2076. https:// doi.org/10.1016/j.biortech.2005.09.011

34. Urrestarazu M, Martínez GA, Salas MDC (2005) Almond shell waste: Possible local rockwool substitute in soilless crop culture. Sci Hortic (Amsterdam) 103:453-460. https://doi.org/10.1016/j. scienta.2004.06.011

35. Samadi A (2011) Effect of particle size distribution of perlite and organic media on cucumber in hydroponic system. Indian J Hortic 66:326-332. https://www.researchgate.net/publication/28618 7937_Effect_of_particle_size_distribution_of_perlite_and_its_ mixture_with_organic_substrates_on_cucumber_in_hydroponics_system. Accessed 29 Aug 2021

36. Goh KM, Haynes RJ (1977) Evaluation of potting media for commercial nursery production of container grown plants: III. effects of media, fertiliser nitrogen, and a nitrification inhibitor on soil nitrification and nitrogen recovery of callistephus chinensis (1.) nees 'pink prince. New Zeal J Agric Res 20:383-393. https://doi. org/10.1080/00288233.1977.10427350

37. Bunt AC (1974) Some physical and chemical characteristics of loamless pot-plant substrates and their relation to plant growth. Acta Hortic. https://doi.org/10.17660/actahortic.1974.37.6

38. Beardsell DV, Nichols DG, Jones DL (1979) Physical properties of nursery potting-mixtures. Sci Hortic (Amsterdam). https://doi. org/10.1016/0304-4238(79)90048-7

39. Jaenicke H (1999) Good tree nursery practices: practical guidelines for research nurseries. Nairobi. http://apps.worldagroforest ry.org/downloads/Publications/PDFS/B14351.pdf. Accessed 29 Aug 2021

40. Wisdom B, Nyembezi M, Agathar K (2017) Effect of different vermiculite and pine bark media substrates mixtures on physical properties and spiral rooting of radish (Raphanus sativus L.) in float tray system. Rhizosphere 3:67-74. https://doi.org/10.1016/j. rhisph.2017.01.002

41. Aghdak P, Mobli M, Khoshgoftarmanesh AH (2016) Effects of different growing media on vegetative and reproductive growth of bell pepper. J Plant Nutr. https://doi.org/10.1080/01904167. 2016.1143494

42. Jayasinghe GY, Arachchi IDL, Tokashiki Y (2010) Evaluation of containerized substrates developed from cattle manure compost and synthetic aggregates for ornamental plant production as a peat alternative. Resour Conserv Recycl. https://doi.org/10. 1016/j.resconrec.2010.06.002 
43. Graceson A, Hare M, Monaghan J, Hall N (2013) The water retention capabilities of growing media for green roofs. Ecol Eng 61:328-334. https://doi.org/10.1016/j.ecoleng.2013.09.030

44. Owen JS, Altland JE (2008) Container height and Douglas fir bark texture affect substrate physical properties. HortScience 43:505-508. https://doi.org/10.21273/hortsci.43.2.505

45. Nguyen VT, Wang CH (2017) Use of organic materials as growing media for honeydew melon seedlings in organic agriculture. Commun Soil Sci Plant Anal. https://doi.org/10.1080/00103624. 2017.1407431

46. Kamaluddin M, Zwiazek JJ (2004) Effects of root medium pH on water transport in paper birch (Betula papyrifera) seedlings in relation to root temperature and abscisic acid treatments. Tree Physiol. https://doi.org/10.1093/treephys/24.10.1173

47. Yang M, Tan L, Xu Y et al (2015) Effect of low pH and aluminum toxicity on the photosynthetic characteristics of different fast-growing Eucalyptus vegetatively propagated clones. PLoS ONE. https://doi.org/10.1371/journal.pone.0130963

48. Ellsworth DS, Xuan L (1994) Photosynthesis and canopy nutrition of four sugar maple forests on acid soils in northern Vermont. Can J For Res. https://doi.org/10.1139/x94-272

49. St. Clair SB, Lynch JP, (2005) Differences in the success of sugar maple and red maple seedlings on acid soils are influenced by nutrient dynamics and light environment. Plant, Cell Environ. https://doi.org/10.1111/j.1365-3040.2005.01337.x

50. Maher M, Prasad M, Raviv M (2008) Organic soilless media components. In: Soilless Culture: Theory and Practice. https:// doi.org/10.1016/B978-044452975-6.50013-7

51. Carlile WR, Cattivello C, Zaccheo P (2015) Organic growing media: constituents and properties. Vadose Zo J. https://doi.org/ 10.2136/vzj2014.09.0125

52. Brust GE (2019) Management strategies for organic vegetable fertility. In: Biswas D, Micallef SA (eds) Safety and Practice for Organic Food. Academic Press, pp 193-212. https://doi.org/10. 1016/B978-0-12-812060-6.00009-X

53. Rousk J, Brookes PC, Bååth E (2009) Contrasting soil pH effects on fungal and bacterial growth suggest functional redundancy in carbon mineralization. Appl Environ Microbiol 75:1589-1596. https://doi.org/10.1128/AEM.02775-08

54. Visconti F, de Paz JM (2016) Electrical conductivity measurements in agriculture: the assessment of soil salinity. In: Cocco L (ed) New Trends and Developments in Metrology. IntechOpen, pp 99-126. https://doi.org/10.5772/62741

55. Ugochukwu UC (2019) Characteristics of clay minerals relevant to bioremediation of environmental contaminated systems. In: Mercurio M, Sarkar B, Langella A (eds) Modified clay and zeolite nanocomposite materials. Elsevier, pp 219-242. https://doi. org/10.1016/B978-0-12-814617-0.00006-2

56. Handreck K, Black N (2010) Growing media for ornamenatl plants and turf, 4th ed. NewSouth Publishing. pp 1-560

57. Lemaire F (1995) Physical, chemical and biological properties of growing medium. Acta Hortic. 273-284. https://doi.org/10. 17660/ActaHortic.1995.396.33

58. Handreck KA (1993) Properties of coir dust, and its use in the formulation of soilless potting media. Commun Soil Sci Plant Anal 24:349-363. https://doi.org/10.1080/00103629309368804

59. Carlile WR, Wilson DP (1991) Microbial activity in growing media - a brief review. Acta Hortic. 197-206. https://doi.org/10. 17660/actahortic.1991.294.21

60. Ghosh PK, Sarma US, Das RA et al (2007) A novel method for accelerated composting of coir pith. Energy Fuels 21:822-827. https://doi.org/10.1021/ef060513c

61. Montesinos-Navarro A, Segarra-Moragues JG, Valiente-Banuet A, Verdú M (2012) The network structure of plant-arbuscular mycorrhizal fungi. New Phytol 194:536-547. https://doi.org/10. 1111/j.1469-8137.2011.04045.x
62. Alexander A, Singh VK, Mishra A, Jha B (2019) Plant growth promoting rhizobacterium Stenotrophomonas maltophilia BJ01 augments endurance against $\mathrm{N}_{2}$ starvation by modulating physiology and biochemical activities of Arachis hypogea. PLoS ONE 14:1-20. https://doi.org/10.1371/journal.pone.0222405

63. Radhapriya P, Ramachandran A, Anandham R, Mahalingam S (2015) Pseudomonas aeruginosa RRALC3 enhances the biomass, nutrient and carbon contents of Pongamia pinnata seedlings in degraded forest soil. PLoS ONE 10:1-19. https://doi.org/ 10.1371/journal.pone.0139881

64. Hashem A, Tabassum B, Fathi Abd_Allah E (2019) Bacillus subtilis: a plant-growth promoting rhizobacterium that also impacts biotic stress. Saudi J Biol Sci 26:1291-1297. https://doi.org/10. 1016/j.sjbs.2019.05.004

65. Singh P, Sharma D (2019) Response of Trichoderma viride and plant growth promoting rhizobacteria (PGPR) on growth and yield of chilli cv. Arka Lohit J Pharmacogn Phytochem 8:1495-1497

66. Singh RP, Jha PN (2016) The multifarious PGPR Serratia marcescens CDP-13 augments induced systemic resistance and enhanced salinity tolerance of wheat (Triticum aestivum L.). PLoS ONE 11:1-24. https://doi.org/10.1371/journal.pone.01550 26

67. Velázquez-Becerra C, Macías-Rodríguez LI, López-Bucio J et al (2011) A volatile organic compound analysis from Arthrobacter agilis identifies dimethylhexadecylamine, an amino-containing lipid modulating bacterial growth and Medicago sativa morphogenesis in vitro. Plant Soil 339:329-340. https://doi.org/10.1007/ s11104-010-0583-Z

68. Hewavitharana N, Kannangara S (2019) Evaluation of organic potting media enriched with Trichoderma spp. and their effect on growth performance of selected vegetables. ijsar.in 6:13-25

69. del Cappellari L, R, Santoro MV, Nievas F, et al (2013) Increase of secondary metabolite content in marigold by inoculation with plant growth-promoting rhizobacteria. Appl Soil Ecol. https:// doi.org/10.1016/j.apsoil.2013.04.001

70. Jangir M, Sharma S, Sharma S (2019) Target and non-target effects of dual inoculation of biocontrol agents against Fusarium wilt in Solanum lycopersicum. Biol Control 138:. https://doi.org/ 10.1016/j.biocontrol.2019.104069

71. Bhattacharyya PN, Jha DK (2012) Plant growth-promoting rhizobacteria (PGPR): emergence in agriculture. World $\mathrm{J}$ Microbiol Biotechnol 28:1327-1350. https://doi.org/10.1007/ s11274-011-0979-9

72. Olanrewaju OS, Glick BR, Babalola OO (2017) Mechanisms of action of plant growth promoting bacteria. World J Microbiol Biotechnol 33:. https://doi.org/10.1007/s11274-017-2364-9

73. Hoffman BM, Lukoyanov D, Yang Z-Y et al (2014) Mechanism of nitrogen fixation by nitrogenase: the next stage. Chem Rev 114:4041-4062. https://doi.org/10.1021/cr400641x

74. Rajkumar M, Ae N, Prasad MNV, Freitas H (2010) Potential of siderophore-producing bacteria for improving heavy metal phytoextraction. Trends Biotechnol 28:142-149. https://doi.org/10. 1016/j.tibtech.2009.12.002

75. Raymond KN, Dertz EA (2004) Biochemical and physical properties of siderophores. In: Jorge H. Crosa, Alexandra R. Mey SMP (ed) Iron transport in bacteria. John Wiley \& Sons, Ltd, pp 1-17. https://doi.org/10.1128/9781555816544.ch1

76. Patten CL, Glick BR (1996) Bacterial biosynthesis of indole3-acetic acid. Can J Microbiol 42:207-220. https://doi.org/10. 1139/m96-032

77. Glick BR (2012) Plant Growth-promoting bacteria: mechanisms and applications. Scientifica (Cairo) 2012:963401. https://doi. org/10.6064/2012/963401

78. Herrera W, Valbuena O, Pavone-Maniscalco D (2020) Formulation of Trichoderma asperellum TV190 for biological control 
of Rhizoctonia solani on corn seedlings. Egypt J Biol Pest Control 30:. https://doi.org/10.1186/s41938-020-00246-9

79. Martínez-Medina A, Roldán A, Pascual JA (2009) Performance of a Trichoderma harzianum bentonite-vermiculite formulation against Fusarium wilt in seedling nursery melon plants. HortScience 44:2025-2027. https://doi.org/10.21273/hortsci. 44.7.2025

80. Berg G, Grube M, Schloter M, Smalla K (2014) Unraveling the plant microbiome: looking back and future perspectives. Front Microbiol 5:1-7. https://doi.org/10.3389/fmicb.2014.00148

81. Grunert O, Hernandez-Sanabria E, Vilchez-Vargas R et al (2016) Mineral and organic growing media have distinct community structure, stability and functionality in soilless culture systems. Sci Rep 6:18837. https://doi.org/10.1038/srep18837

82. Koohakan P, Ikeda H, Jeanaksorn T et al (2004) Evaluation of the indigenous microorganisms in soilless culture: occurrence and quantitative characteristics in the different growing systems. Sci Hortic (Amsterdam) 101:179-188. https://doi.org/10.1016/j. scienta.2003.09.012

83. Van Gerrewey T, Vandecruys M, Ameloot N et al (2020) Microbe-plant growing media interactions modulate the effectiveness of bacterial amendments on lettuce performance inside a plant factory with artificial lighting. Agronomy 10:1456. https:// doi.org/10.3390/agronomy 10101456

84. Vandecasteele B, Muylle H, De Windt I et al (2018) Plant fibers for renewable growing media: Potential of defibration, acidification or inoculation with biocontrol fungi to reduce the $\mathrm{N}$ drawdown and plant pathogens. J Clean Prod 203:1143-1154. https:// doi.org/10.1016/j.jclepro.2018.08.167

85. Debode J, De Tender C, Cremelie P et al (2018) Trichodermainoculated miscanthus straw can replace peat in strawberry cultivation, with beneficial effects on disease control. Front Plant Sci 9:1-15. https://doi.org/10.3389/fpls.2018.00213

86. Nerlich A, Dannehl D (2021) Soilless cultivation: dynamically changing chemical properties and physical conditions of organic substrates influence the plant phenotype of lettuce. Front Plant Sci 11:1-13. https://doi.org/10.3389/fpls.2020.601455

87. Moyano FE, Manzoni S, Chenu C (2013) Responses of soil heterotrophic respiration to moisture availability: an exploration of processes and models. Soil Biol Biochem 59:72-85. https://doi. org/10.1016/j.soilbio.2013.01.002

88. Heiskanen J (1995) Physical properties of two-component growth media based on Sphagnum peat and their implications for plantavailable water and aeration. Plant Soil 172:45-54. https://doi. org/10.1007/BF00020858

89. Andlar M, Rezić T, Marđetko N et al (2018) Lignocellulose degradation: an overview of fungi and fungal enzymes involved in lignocellulose degradation. Eng Life Sci 18:768-778. https://doi. org/10.1002/elsc.201800039

90. Bhat MK, Bhat S (1997) Cellulose degrading enzymes and their potential industrial applications. Biotechnol Adv 15:583-620. https://doi.org/10.1016/S0734-9750(97)00006-2

91. Takahashi M, Yamamoto R, Sakurai N et al (2015) Fungal hemicellulose-degrading enzymes cause physical property changes concomitant with solubilization of cell wall polysaccharides. Planta 241:359-370. https://doi.org/10.1007/s00425-014-2176-1

92. Janusz G, Pawlik A, Sulej J et al (2017) Lignin degradation: microorganisms, enzymes involved, genomes analysis and evolution. FEMS Microbiol Rev 41:941-962. https://doi.org/10.1093/ femsre/fux049

93. Carlile WR (2004) Changes in organic growing media during storage. Acta Hortic 648:153-159. https://doi.org/10.17660/ ActaHortic.2004.648.18

94. Drobnik J, Stebel A (2017) Tangled history of the European uses of Sphagnum moss and sphagnol. J Ethnopharmacol 209:41-49. https://doi.org/10.1016/j.jep.2017.07.025
95. Tahvonen R, Kemppainen R (2008) Microbiological variation in self-heated and non-self-heated sphagnum peat and its effect on growth of plants. Acta Hortic 779:75-78. https://doi.org/10. 17660/ActaHortic.2008.779.6

96. Wever G, Hertogh-Pon MH (1993) Effects of self-heating on biological, chemical and physical characteristics of peat. Acta Hortic. https://doi.org/10.17660/actahortic.1993.342.2

97. Verhagen JBGM, Boon HTM (2008) Classification of growing media on their environmental profile. Acta Hortic 779:231-238. https://doi.org/10.17660/ActaHortic.2008.779.28

98. Barrett GE, Alexander PD, Robinson JS, Bragg NC (2016) Achieving environmentally sustainable growing media for soilless plant cultivation systems - a review. Sci Hortic (Amsterdam) 212:220-234. https://doi.org/10.1016/j.scienta.2016.09.030

99. Orru M, Orru H (2008) Sustainable use of Estonian peat reserves and environmental challenges. Est J Earth Sci 57:87-93. https:// doi.org/10.3176/earth.2008.2.04

100. Wieder RK, Vitt DH, Benscoter BW (2006) Peatlands and the boreal forest. In: Wieder RK, Vitt DH (eds) Boreal peatland ecosystems. Springer, Berlin, pp 1-8. https://doi.org/10.1007/ 978-3-540-31913-9_1

101. Rikala R, Heiskanen J (1995) Variation in the electrical conductivity and acidity of preculture peat growth media used in finnish tree nurseries. Scand J For Res. https://doi.org/10.1080/02827 589509382880

102. Chemetova C, Quilhó T, Braga S et al (2019) Aged Acacia melanoxylon bark as an organic peat replacement in container media. J Clean Prod 232:1103-1111. https://doi.org/10.1016/j.jclepro. 2019.06.064

103. Gruda NS (2019) Increasing sustainability of growing media constituents and stand-alone substrates in soilless culture systems. Agronomy 9:1-24. https://doi.org/10.3390/agronomy9060298

104. Chemetova C, Mota D, Fabião A, et al (2017) Valorization of Eucalyptus globulus bark as a growing-media component for potted plants. In: Conference on Environmental Science and Technology. https://cest2017.gnest.org/sites/default/files/prese ntation_file_list/cest2017_00437_poster_paper.pdf. Accessed 29 Aug 2021

105. Buamscha MG, Altland JE, Sullivan DM, et al (2008) Nitrogen availability in fresh and aged douglas fir bark. Horttechnology 18:619-623. https://doi.org/10.21273/horttech.18.4.619

106. Trillas MI, Casanova E, Cotxarrera L et al (2006) Composts from agricultural waste and the Trichoderma asperellum strain T-34 suppress Rhizoctonia solani in cucumber seedlings. Biol Control 39:32-38. https://doi.org/10.1016/j.biocontrol.2006.05.007

107. Nelson EB (1983) The role of microorganisms in the suppression of rhizoctonia solani in container media amended with composted hardwood bark. Phytopathology 73:274-278. https://doi. org/10.1094/phyto-73-274

108. Hardy GESJ, Sivasithamparam K (1995) Antagonism of fungi and actinomycetes isolated from composted eucalyptus bark to Phytophthora drechsleri in a steamed and non-steamed composted eucalyptus bark-amended container medium. Soil Biol Biochem 27:243-246. https://doi.org/10.1016/0038-0717(94) 00172-W

109. Prasad M, Maher MJ (2004) Stability of peat alternatives and use of moderately decomposed peat as a structure builder in growing media. Acta Hortic. https://doi.org/10.17660/ActaHortic.2004. 648.17

110. Domeño I, Irigoyen I, Muro J (2010) New wood fibre substrates characterization and evaluation in hydroponic tomato culture. Eur J Hortic Sci 75:89-94. https://woodsubstrates.cals.ncsu.edu/ files/2020/02/new-wood-fibre-substrates.pdf. Accessed 29 Aug 2021

111. Burgel L, Hartung J, Graeff-Hönninger S (2020) Impact of different growing substrates on growth, yield and cannabinoid content 
of two cannabis sativa L. genotypes in a pot culture. Horticulturae. https://doi.org/10.3390/horticulturae6040062

112. Coirpith Wealth From Waste (2016). In: Minist. Micro, Small Mediu. Enterp. Gov. India. http://coirboard.gov.in/wp-content/ uploads/2016/07/Coir-Pith.pdf. Accessed 15 Feb 2021

113. Meerow A (1997) Coir dust, a viable alternative to peat moss. Greenh Prod News. https://www.researchgate.net/publication/ 239530350_Coir_Dust_A_Viable_Alternative_to_Peat_Moss. Accessed 29 Aug 2021

114. Arenas M, Vavrina CS, Cornell JA, et al (2002) Coir as an alternative to peat in media for tomato transplant production. HortScience. https://doi.org/10.21273/hortsci.37.2.309

115. Evans MR, Stamps RH (1996) Growth of bedding plants in sphagnum peat and coir dust-based substrates. J Environ Hortic 14:187-190. https://doi.org/10.24266/0738-2898-14.4.187

116. De Kreij C, Van Leeuwen GJL (2001) Growth of pot plants in treated coir dust as compared to peat. Commun Soil Sci Plant Anal 32:2255-2265. https://doi.org/10.1081/CSS-120000281

117. Gruda $N$ (2012) Current and future perspective of growing media in Europe. Acta Hortic 960:37-43. https://doi.org/10.17660/ ActaHortic.2012.960.3

118. Blok C, Wever G (2008) Experience with selected physical methods to characterize the suitability of growing media for plant growth. Acta Hortic 779:239-250. https://doi.org/10.17660/actah ortic.2008.779.29

119. Nelson P V, Oh Y-M, Cassel DK (2004) Changes in physical properties of coir dust substrates during crop production. Acta Hortic 644:261-268. https://doi.org/10.17660/ActaHortic.2004. 644.35

120. Silber A (2019) Chemical characteristics of soilless media. In: Soilless culture: theory and practice, second edi. Elsevier, Academic Press, pp 113-148. https://doi.org/10.1016/B978-04445 2975-6.50008-3

121. Prabhu SR, Thomas GV (2002) Biological conversion of coir pith into a value-added organic resource and its application in agrihorticulture: current status, prospects and perspective. J Plant Crop 30:1-17

122. Udayana SK, Naorem A, Singh NA (2017) The multipurpose utilization of coconut by-products in agriculture: prospects and concerns. Int J Curr Microbiol Appl Sci 6:1408-1415. https:// doi.org/10.20546/ijcmas.2017.606.165

123. Export of Coir and Coir products from India. In: Coir Board, Minist. Micro, Small Mediu. Enterp. Gov. India. http://coirboard. gov.in/wp-content/uploads/2021/01/Last-5-Years-Export-201920.pdf. Accessed 15 Feb 2021

124. Association of American Plant Food Control Officials (2017) AAPFCO product label guide. http://www.aapfco.org/pdf/produ ct_label_guide.pdf. Accessed 15 Feb 2021

125. Gondek M, Weindorf DC, Thiel C, Kleinheinz G (2020) Soluble salts in compost and their effects on soil and plants: a review. Compost Sci Util 28:59-75. https://doi.org/10.1080/1065657X. 2020.1772906

126. Zhang D, Luo W, Li Y et al (2018) Performance of co-composting sewage sludge and organic fraction of municipal solid waste at different proportions. Bioresour Technol. https://doi.org/10. 1016/j.biortech.2017.08.136

127. Pardo T, Clemente R, Bernal MP (2011) Effects of compost, pig slurry and lime on trace element solubility and toxicity in two soils differently affected by mining activities. Chemosphere 84:642-650. https://doi.org/10.1016/j.chemosphere.2011.03.037

128. Stewart-Wade SM (2020) Efficacy of organic amendments used in containerized plant production: Part 1 - Compost-based amendments. Sci Hortic (Amsterdam) 266:108856. https://doi. org/10.1016/j.scienta.2019.108856

129. Bustamante MA, Gomis MP, Pérez-Murcia MD et al (2021) Use of livestock waste composts as nursery growing media: effect of a washing pre-treatment. Sci Hortic (Amsterdam) 281:109954. https://doi.org/10.1016/j.scienta.2021.109954

130. van der Gaag DJ, van Noort FR, Stapel-Cuijpers LHM et al (2007) The use of green waste compost in peat-based potting mixtures: Fertilization and suppressiveness against soilborne diseases. Sci Hortic (Amsterdam) 114:289-297. https://doi.org/ 10.1016/j.scienta.2007.06.018

131. Carballo T, Gil MV, Calvo LF, Morán A (2009) The influence of aeration system, temperature and compost origin on the phytotoxicity of compost tea. Compost Sci Util 17:127-139. https:// doi.org/10.1080/1065657X.2009.10702411

132. Smith M (2018) Do microplastic residuals in municipal compost bioaccumulate in plant tissue?

133. Suo LN, Sun XY, Li SY (2011) Use of organic agricultural wastes as growing media for the production of Anthurium andraeanum "Pink Lady." J Hortic Sci Biotechnol 86:366-370. https://doi.org/10.1080/14620316.2011.11512775

134. Lazcano C, Arnold J, Tato A et al (2009) Compost and vermicompost as nursery pot components: effects on tomato plant growth and morphology. Spanish J Agric Res. https://doi.org/10. 5424/sjar/2009074-1107

135. Hernández-Apaolaza L, Gascó AM, Gascó JM, Guerrero F (2005) Reuse of waste materials as growing media for ornamental plants. Bioresour Technol. https://doi.org/10.1016/j.biortech. 2004.02.028

136. Veeken A, Blok WJ, Curci F, et al (2005) Improving quality of composted biowaste to enhance disease suppressiveness of compost-amended, peat-based potting mixes. Soil Biol Biochem 37:. https://doi.org/10.1016/j.soilbio.2005.03.018

137. Costello RC, Sullivan DM, Bryla DR, et al (2019) Compost feedstock and compost acidification affect growth and mineral nutrition in Northern Highbush Blueberry. HortScience 54:10671076. https://doi.org/10.21273/HORTSCI13599-18

138. Bilderback TE, Fonteno WC, Johnson DR et al (1982) Physical properties of media composed of peanut hulls pine bark and peat moss and their effects on azalea rhododendron indicum growth. J Am Soc Hortic Sci 107:522-525

139. Bonaguro JE, Coletto L, Zanin G (2017) Environmental and agronomic performance of fresh rice hulls used as growing medium component for Cyclamen persicum L. pot plants. J Clean Prod 142:2125-2132. https://doi.org/10.1016/j.jclepro.2016.11. 071

140. Zanin G, Coletto L, Passoni M, et al (2016) Organic by-product substrate components and biodegradable pots in the production of Pelargonium $\times$ hortorum Bailey and Euphorbia pulcherrima L. In: Acta Horticulturae. https://doi.org/10.17660/ActaHortic. 2016.1112.50

141. Altland J (2010) Use of processed biofuel crops for nursery substrates. J Environ Hortic 28:129-134. https://doi.org/10.24266/ 0738-2898-28.3.129

142. Altland J, Locke J (2011) Use of ground miscanthus straw in container nursery substrates. J Environ Hortic 29:114-118. https:// doi.org/10.24266/0738-2898-29.3.114

143. Locke JC, Altland JE (2012) Use of ground wheat straw in container nursery substrates to overwinter daylily divisions. J Environ Hortic 30:207-210. https://doi.org/10.24266/0738-2898. 30.4.207

144. Ruis SJ, Blanco-Canqui H, Paparozzi ET, Zeeck R (2019) Using processed corn stover as an alternative to peat. HortScience 54:385-394. https://doi.org/10.21273/HORTSCI13453-18

145. Yue XH, Miao LF, Yang F, Nawaz M (2020) Morphological and physiological responses of Dalbergia odorifera T. Chen seedlings to different culture substances. PLoS ONE 15:1-16. https:// doi.org/10.1371/journal.pone.0232051

146. Evans MR, Vancey L (2007) Physical properties of processed poultry feather fiber-containing greenhouse root substrates. 
Horttechnology 17:301-304. https://doi.org/10.21273/horttech. 17.3.301

147. Benedetto D, Adalberto PJC et al (2006) Evaluation of alternative substrates for bedding plants. Int J Agric Res 1:545-554

148. Singh A, Karmegam N, Singh GS et al (2020) Earthworms and vermicompost: an eco-friendly approach for repaying nature's debt. Environ Geochem Health 42:1617-1642. https://doi.org/ 10.1007/s10653-019-00510-4

149. Arancon NQ, Edwards CA, Babenko A et al (2008) Influences of vermicomposts, produced by earthworms and microorganisms from cattle manure, food waste and paper waste, on the germination, growth and flowering of petunias in the greenhouse. Appl Soil Ecol. https://doi.org/10.1016/j.apsoil.2007.11.010

150. Orozco FH, Cegarra J, Trujillo LM, Roig A (1996) Vermicomposting of coffee pulp using the earthworm Eisenia fetida: effects on $\mathrm{C}$ and $\mathrm{N}$ contents and the availability of nutrients. Biol Fertil Soils. https://doi.org/10.1007/BF00384449

151. Arancon NQ, Edwards CA, Lee S, Byrne R (2006) Effects of humic acids from vermicomposts on plant growth. Eur J Soil Biol. https://doi.org/10.1016/j.ejsobi.2006.06.004

152. Nikbakht A, Kafi M, Babalar M et al (2008) Effect of humic acid on plant growth, nutrient uptake, and postharvest life of gerbera. J Plant Nutr. https://doi.org/10.1080/01904160802462819

153. Atiyeh RM, Edwards CA, Subler S, Metzger JD (2000) Earthworm-processed organic wastes as components of horticultural potting media for growing marigold and vegetable seedlings. Compost Sci Util 8:215-223. https://doi.org/10.1080/1065657X. 2000.10701994

154. Coulibaly SS, Edoukou FE, Kouassi KI, et al (2018) Vermicompost utilization: a way to food security in rural area. Heliyon 4:. https://doi.org/10.1016/j.heliyon.2018.e01104

155. Tomati U, Grappelli A, Galli E (1988) The hormone-like effect of earthworm casts on plant growth. Biol Fertil Soils. https://doi. org/10.1007/BF00262133

156. Demir Z (2020) Alleviation of adverse effects of sodium on soil physicochemical properties by application of vermicompost. Compost Sci Util. https://doi.org/10.1080/1065657X.2020.17890 11

157. Manh VH, Wang CH (2014) Vermicompost as an important component in substrate: effects on seedling quality and growth of muskmelon (Cucumis melo L.). APCBEE Procedia. https://doi. org/10.1016/j.apcbee.2014.01.076

158. Wang XX, Zhao F, Zhang G et al (2017) Vermicompost improves tomato yield and quality and the biochemical properties of soils with different tomato planting history in a greenhouse study. Front Plant Sci. https://doi.org/10.3389/fpls.2017.01978

159. Abbey L, Young C, Teitel-Payne R, Howe K (2012) Evaluation of proportions of vermicompost and coir in a medium for containerGrown Swiss Chard. Int J Veg Sci. https://doi.org/10.1080/19315 260.2011.585702

160. Conversa G, Bonasia A, Lazzizera C, Elia A (2015) Influence of biochar, mycorrhizal inoculation, and fertilizer rate on growth and flowering of Pelargonium (Pelargonium zonale L.) plants. Front Plant Sci 6:429. https://doi.org/10.3389/fpls.2015.00429

161. Steiner C, Harttung $T$ (2014) Biochar as growing media additive and peat substitute. Solid Earth Discuss 6:1023-1035. https://doi. org/10.5194/sed-6-1023-2014

162. Headlee WL, Brewer CE, Hall RB (2014) Biochar as a substitute for vermiculite in potting mix for hybrid poplar. Bioenergy Res 7:120-131. https://doi.org/10.1007/s12155-013-9355-y

163. Locke JC, Altland JE, Ford CW (2013) Gasified rice hull biochar affects nutrition and growth of horticultural crops in container substrates. J Environ Hortic 31:195-202. https://doi.org/10. 24266/0738-2898.31.4.195

164. Méndez A, Paz-Ferreiro J, Gil E, Gascó G (2015) The effect of paper sludge and biochar addition on brown peat and coir based growing media properties. Sci Hortic (Amsterdam) 193:225-230. https://doi.org/10.1016/j.scienta.2015.07.032

165. Zhang L, Sun X, yang, Tian Y, Gong X qiang, (2014) Biochar and humic acid amendments improve the quality of composted green waste as a growth medium for the ornamental plant Calathea insignis. Sci Hortic (Amsterdam) 176:70-78. https://doi.org/ 10.1016/j.scienta.2014.06.021

166. Warnock DD, Lehmann J, Kuyper TW, Rillig MC (2007) Mycorrhizal responses to biochar in soil - concepts and mechanisms. Plant Soil 300:9-20. https://doi.org/10.1007/s11104-007-9391-5

167. Głodowska M, Husk B, Schwinghamer T, Smith D (2016) Biochar is a growth-promoting alternative to peat moss for the inoculation of corn with a pseudomonad. Agron Sustain Dev 36:21. https://doi.org/10.1007/s13593-016-0356-z

168. Vecstaudza D, Senkovs M, Nikolajeva V et al (2017) Wooden biochar as a carrier for endophytic isolates. Rhizosphere 3:126127. https://doi.org/10.1016/j.rhisph.2017.04.002

169. Amery F, Debode J, Ommeslag S, et al (2021) Biochar for circular horticulture: feedstock related effects in soilless cultivation. Agronomy 11:. https://doi.org/10.3390/agronomy 11040629

170. Song W, Guo M (2012) Quality variations of poultry litter biochar generated at different pyrolysis temperatures. J Anal Appl Pyrolysis 94:138-145. https://doi.org/10.1016/j.jaap.2011.11.018

171. Nieto A, Gascó G, Paz-Ferreiro J et al (2016) The effect of pruning waste and biochar addition on brown peat based growing media properties. Sci Hortic (Amsterdam) 199:142-148. https:// doi.org/10.1016/j.scienta.2015.12.012

172. Tian Y, Sun X, Li S et al (2012) Biochar made from green waste as peat substitute in growth media for Calathea rotundifola cv. Fasciata Sci Hortic (Amsterdam) 143:15-18. https://doi.org/10. 1016/j.scienta.2012.05.018

173. Papadopoulos A, Bar-Tal A, Silber A, et al (2008) Inorganic and synthetic organic components of soilless culture and potting mixes. In: Soilless culture: theory and practice. pp 505-543. https://doi.org/10.1016/B978-044452975-6.50014-9

174. Kaniszewski S, Dyśko J, Kowalczyk W et al (2010) Effect of nitration of organic materials on nitrogen availability and yield of tomato in soilless culture. Veg Crop Res Bull 72:71-81. https:// doi.org/10.2478/v10032-010-0007-x

175. Hoitink HAJ, Boehm M (1999) Biocontrol within the context of soil microbial communities: a substrate-dependent phenomenon. Annu Rev Phytopathol 37:427-446. https://doi.org/10.1146/ annurev.phyto.37.1.427

176. Sunil L, Appaiah P, Kumar PKP (2015) Preparation of food supplements from oilseed cakes. J Food Sci Technol 52:2998-3005. https://doi.org/10.1007/s13197-014-1386-7

177. Sarker AK, Saha D, Begum H, et al (2015) Comparison of cake compositions, pepsin digestibility and amino acids concentration of proteins isolated from black mustard and yellow mustard cakes. AMB Express 5:. https://doi.org/10.1186/ s13568-015-0110-y

178. Bhattacharya D, Goswami B (1987) Comparative efficacy of neem and groundnut oil-cakes with aldicarb against meloidogyne incognita in tomato. Rev nématologie 10:467-470

179. Radwan MA, El-Maadawy EK, Kassem SI, Abu-Elamayem MM (2009) Oil cakes soil amendment effects on Meloidogyne incognita, root-knot nematode infecting tomato. Arch Phytopathol Plant Prot. https://doi.org/10.1080/03235400600940830

180. Sumbul A, Rizvi R, Mahmood I, Ali Ansari R (2015) Oil-cake amendments: useful tools for the management of phytonematodes. Asian J Plant Pathol. https://doi.org/10.3923/ajppaj.2015. 91.111

181. Rizvi R, Singh G, Safiuddin, et al (2015) Sustainable management of root-knot disease of tomato by neem cake and Glomus fasciculatum. Cogent Food Agric. https://doi.org/10.1080/23311 932.2015.1008859 
182. Parveen G, Mukhtar N, Kaleemullah, Sheikh MK (2019) Enhancement of growth and suppressing the root diseases of tomato plant by using organic amendment. Pure Appl Biol. https://doi.org/10.19045/bspab.2019.80051

183. Oyinlola E, Paul O, E.O U (2017) Effect of neem seed cake and inorganic fertilizer on yield of tomato and soil properties in northern guinea savanna of nigeria. Eur J Agric For Res 5:1-15. https://www.researchgate.net/publication/323014678_ effect_of_neem_seed_cake_and_inorganic_fertilizer_on_ yield_of_tomato_and_soil_properties_in_northern_guinea_ savanna_of_nigeria. Accessed 29 Aug 2021

184. Vaughn SF, Deppe NA, Berhow MA, Evangelista RL (2010) Lesquerella press cake as an organic fertilizer for greenhouse tomatoes. Ind Crops Prod. https://doi.org/10.1016/j.indcrop. 2010.04.008

185. Lima RLS, Severino LS, Sampaio LR et al (2011) Blends of castor meal and castor husks for optimized use as organic fertilizer. Ind Crops Prod. https://doi.org/10.1016/j.indcrop.2010. 11.008

186. Gupta AP, Antil RS, Narwal RP (2004) Utilization of deoiled castor cake for crop production. Arch Agron Soil Sci. https:// doi.org/10.1080/03650340410001663891

187. Ahluwalia S (2018) Effect of raw, defatted and detoxified Jatropha seed cake on germination of green gram (Vigna radiata). Int J Res Appl Sci Eng Technol 6:1033-1041. https://doi.org/ 10.22214/ijraset.2018.1156

188. Mondal S, Das R, Das AC (2014) A comparative study on the decomposition of edible and non-edible oil cakes in the Gangetic alluvial soil of West Bengal. 5199-5207. https://doi. org/10.1007/s10661-014-3769-7

189. Rogato AL japonicus, D'Apuzzo E, Chiurazzi M (2010) The multiple plant response to high ammonium conditions: the Lotus japonicus AMT1; 3 protein acts as a putative transceptor. Plant Signal Behav 5:1594-1596. https://doi.org/10.4161/ psb.5.12.13856

190. Pratibha SS, Hariprasad P (2020) Development and evaluation of deoiled seed cake and paddy straw amended potting media for the cultivation of tomato and cucumber. Waste and Biomass Valorization. https://doi.org/10.1007/s12649-020-01264-2

191. Zhang G, Kazanietz MG, Blumberg PM, Hurley JH (1995) Crystal structure of the Cys2 activator-binding domain of protein kinase $\mathrm{C} \delta$ in complex with phorbol ester. Cell. https://doi. org/10.1016/0092-8674(95)90011-X

192. King A, He W, Cuevas J et al (2009) Potential of Jatropha curcas as a source of renewable oil and animal feed. J Exp Bot 60:2897-2905. https://doi.org/10.1093/jxb/erp025

193. Andrade LF, Davide LC, Gedraite LS (2010) The effect of cyanide compounds, fluorides, aluminum, and inorganic oxides present in spent pot liner on germination and root tip cells of Lactuca sativa. Ecotoxicol Environ Saf. https://doi.org/10. 1016/j.ecoenv.2009.12.012

194. Wang XH, Ou L, Fu LL et al (2013) Detoxification of Jatropha curcas kernel cake by a novel Streptomyces fimicarius strain. J Hazard Mater. https://doi.org/10.1016/j.jhazmat.2013.05.012

195. Bhattacharyya P, Bhaduri D, Adak T et al (2020) Characterization of rice straw from major cultivars for best alternative industrial uses to cutoff the menace of straw burning. Ind Crops Prod 143:111919. https://doi.org/10.1016/j.indcrop.2019. 111919

196. Trivedi A, Verma AR, Kaur S et al (2017) Sustainable bio-energy production models for eradicating open field burning of paddy straw in Punjab. Energy, India. https://doi.org/10.1016/j.energy. 2017.03.138

197. Singh J (2018) Paddy and wheat stubble blazing in Haryana and Punjab states of India: A menace for environmental health. Environ Qual Manag. https://doi.org/10.1002/tqem.21598
198. Kim Oanh NT, Ly BT, Tipayarom D et al (2011) Characterization of particulate matter emission from open burning of rice straw. Atmos Environ. https://doi.org/10.1016/j.atmosenv. 2010.09.023

199. Singh G, Tiwari A, Rathore H, et al (2020) Valorization of paddy straw using de-oiled cakes for $P$. ostreatus cultivation and utilization of spent mushroom substrate for biopesticide development. Waste and Biomass Valorization. https://doi.org/10.1007/ s12649-020-00957-y

200. Shoaib AM, El-Adly RA, Hassanean MHM et al (2018) Developing a free-fall reactor for rice straw fast pyrolysis to produce bio-products. Egypt J Pet. https://doi.org/10.1016/j.ejpe.2018.08. 002

201. Chivenge P, Rubianes F, Van Chin D, et al (2020) Rice straw incorporation influences nutrient cycling and soil organic matter. In: Gummert M, Hung N Van, Chivenge P, Douthwaite B (eds) Sustainable Rice Straw Management. Springer International Publishing, Cham, pp 131-144. https://doi.org/10.1007/ 978-3-030-32373-8_8

202. Kowalska J, Tyburski J, Jakubowska M, Krzymińska J (2021) Effect of different forms of silicon on growth of spring wheat cultivated in organic farming system. SILICON. https://doi.org/ 10.1007/s12633-020-00414-4

203. Luyckx M, Hausman JF, Lutts S, Guerriero G (2017) Silicon and plants: current knowledge and technological perspectives. Front Plant Sci. https://doi.org/10.3389/fpls.2017.00411

204. Currie HA, Perry CC (2007) Silica in plants: biological, biochemical and chemical studies. Ann Bot. https://doi.org/10.1093/ aob/mcm 247

205. Van Hung N, Maguyon-Detras MC, Migo MV, et al (2020) Rice straw overview: availability, properties, and management practices. In: Gummert M, Hung N Van, Chivenge P, Douthwaite B (eds) Sustainable rice straw management. Springer International Publishing, Cham, pp 1-13. https://doi.org/10.1007/ 978-3-030-32373-8_1

206. Ali HI, Ismail MR, Manan MM, Saudi HM (2006) Rice straw compost and water deficit affect yield, quality and water use efficiency (WUE) of tomatoes grown in different media. Biol Agric Hortic. https://doi.org/10.1080/01448765.2006.9755028

207. Feng J, Zhi Y, Zhang D et al (2020) Rice straw as renewable components of horticultural growing media for purple cabbage. Sci Total Environ. https://doi.org/10.1016/j.scitotenv.2020.141274

208. Ahmed M, Farag A, Abdrabbo M, et al (2015) Utilization of rice straw in tomato production under different levels of water requirements. Egypt J Agric Res 93:377-389. https://www.resea rchgate.net/publication/316243055_utilization_of_rice_straw_ in_tomato_production_under_different_levels_of_water_requi rements. Accessed 29 Aug 2021

209. Farag AA, Ahmed MSM, Hashem FA, et al (2015) Utilization of rice straw and vermicompost in vegetable production via soilless culture. Glob J Adv Res 2:800-813. https://www.researchga te.net/publication/299595199_utilization_of_rice_straw_and_ vermicompost_in_vegetable_production_via_soilless_culture. Accessed 29 Aug 2021

210. El-Marzoky HA, Abdel-Sattar MA (2008) Influence of growing sweet pepper in compacted rice straw bales compared with natural soil, on infection with pathogenic fungi and nematodes under greenhouse conditions. Arab Univ J Agric Sci. https://doi. org/10.21608/ajs.2008.15023

211. Sadek I, Moursy F, Salem E, et al (2014) Enhancing rice straw media for growing eggplant under modified climatic conditions using compost and bacterial inoculation. Nat Sci 12:8-20. https:// www.researchgate.net/publication/317265175_Enhancing_Rice_ Straw_Media_for_Growing_Eggplant_under_Modified_Clima tic_Conditions_Using_Compost_and_Bacterial_Inoculation. Accessed 29 Aug 2021 
212. De Lucia B, Cristiano G, Vecchietti L, et al (2013) Nursery growing media: agronomic and environmental quality assessment of sewage sludge-based compost. Appl Environ Soil Sci 2013: https://doi.org/10.1155/2013/565139

213. Vecchietti L, De Lucia B, Russo G, et al (2013) Environmental and agronomic evaluation of containerized substrates developed from sewage sludge compost for ornamental plant production. Acta Hortic 1013:431-439. https://doi.org/10.17660/ActaHortic. 2013.1013.54

214. Prasad M, Carlile W (2009) Practical experiences and background research on the use of composted materials in growing media for the UK market. In: Acta Hortic. 819. pp 111-124. https://doi.org/10.17660/ActaHortic.2009.819.10

215. Diara C, Incrocci L, Pardossi A, Minuto A (2012) Reusing greenhouse growing media. Acta Hortic 927:793-800. https://doi.org/ 10.17660/ActaHortic.2012.927.98

216. Vandecasteele B, Blindeman L, Amery F et al (2020) Grow store - steam - re-peat: reuse of spent growing media for circular cultivation of Chrysanthemum. J Clean Prod 276:124128. https:// doi.org/10.1016/j.jclepro.2020.124128

217. Zucchi P, Longa CMO, Bertoldi D, et al (2017) Effects of organic substrate reuse on growth and yield of everbearing "Capri" strawberry. Acta Hortic 1156:579-586. https://doi.org/10.17660/ ActaHortic.2017.1156.86

218. Baevre OA, Guttormsen G (1984) Reuse of peat bags for tomatoes and cucumbers. Plant Soil 77:207-214. http://www.jstor.org/ stable/42934527. Accessed 29 Aug 2021

219. Viaene J, Reubens B, Willekens K et al (2017) Potential of chopped heath biomass and spent growth media to replace wood chips as bulking agent for composting high $\mathrm{N}$-containing residues. J Environ Manage 197:338-350. https://doi.org/10.1016/j. jenvman.2017.03.086

220. Bussell WT, McKennie S (2004) Rockwool in horticulture, and its importance and sustainable use in New Zealand. New Zeal J Crop Hortic Sci 32:29-37. https://doi.org/10.1080/01140671. 2004.9514277

221. Caporn SJM, Hutchinson TC (1986) The contrasting response to simulated acid rain of leaves and cotyledons of cabbage (Brassica oleracea L.). New Phytol. https://doi.org/10.1111/j.1469-8137. 1986.tb00618.x
222. Follmer CM, Hummes AP, Lângaro NC et al (2021) Nutrient availability and $\mathrm{pH}$ level affect germination traits and seedling development of Conyza canadensis. Sci Rep 11:15607. https:// doi.org/10.1038/s41598-021-95164-7

223. Fernández FG, Hoeft RG Managing soil $\mathrm{pH}$ and crop nutrients. In: Illinois Agron. Handb. http://extension.cropsciences.illinois. edu/handbook/pdfs/chapter08.pdf. Accessed 6 Sep 2021

224. Costa-Gutierrez SB, Lami MJ, Di SMCC et al (2020) Plant growth promotion by Pseudomonas putida KT2440 under saline stress: role of eptA. Appl Microbiol Biotechnol 104:4577-4592. https://doi.org/10.1007/s00253-020-10516-Z

225. Ding X, Jiang Y, Zhao H et al (2018) Electrical conductivity of nutrient solution influenced photosynthesis, quality, and antioxidant enzyme activity of pakchoi (Brassica campestris L. Ssp. Chinensis) in a hydroponic system. PLoS ONE 13:1-15. https:// doi.org/10.1371/journal.pone.0202090

226. Akratos CS, Tekerlekopoulou AG, Vasiliadou IA, Vayenas D V. (2017) Cocomposting of olive mill waste for the production of soil amendments. In: Olive mill waste: recent advances for sustainable management. Elsevier Inc., pp 161-182. https://doi. org/10.1016/B978-0-12-805314-0.00008-X

227. Leite MFA, Pan Y, Bloem J et al (2017) Organic nitrogen rearranges both structure and activity of the soil-borne microbial seedbank. Sci Rep 7:42634. https://doi.org/10.1038/srep42634

228. Mohanty M, Sinha NK, Sammi Reddy K et al (2013) How important is the quality of organic amendments in relation to mineral $\mathrm{N}$ availability in soils? Agric Res 2:99-110. https://doi.org/10. 1007/s40003-013-0052-z

229. Dannehl D, Suhl J, Ulrichs C, Schmidt U (2015) Evaluation of substitutes for rock wool as growing substrate for hydroponic tomato production. J Appl Bot Food Qual. https://doi.org/10. 5073/JABFQ.2015.088.010

Publisher's note Springer Nature remains neutral with regard to jurisdictional claims in published maps and institutional affiliations. 